\title{
Examining open source investment aggressiveness of large computer and telecommunication firms
}

\author{
By
}

Feng Li

A thesis submitted to the Faculty of Graduate Studies and Research in partial fulfillment of the requirements for the degree of Master of Applied Science in Technology Innovation Management

Department of Systems and Computer Engineering,

Carleton University

Ottawa, Ontario

CANADA

August 2006

Copyright $\odot 2006$, Feng Li 


$\begin{array}{ll}\begin{array}{l}\text { Library and } \\ \text { Archives Canada }\end{array} & \begin{array}{l}\text { Bibliothèque et } \\ \text { Archives Canada }\end{array} \\ \begin{array}{l}\text { Published Heritage } \\ \text { Branch }\end{array} & \begin{array}{l}\text { Direction du } \\ \text { Patrimoine de l'édition }\end{array} \\ \begin{array}{l}\text { 395 Wellington Street } \\ \text { Ottawa ON K1A ON4 }\end{array} & \begin{array}{l}\text { 395, rue Wellington } \\ \text { Ottawa ON K1A ON4 } \\ \text { Canada }\end{array}\end{array}$

Your file Votre référence ISBN: 978-0-494-18323-6 Our file Notre référence ISBN: 978-0-494-18323-6

NOTICE:

The author has granted a nonexclusive license allowing Library and Archives Canada to reproduce, publish, archive, preserve, conserve, communicate to the public by telecommunication or on the Internet, loan, distribute and sell theses worldwide, for commercial or noncommercial purposes, in microform, paper, electronic and/or any other formats.

The author retains copyright ownership and moral rights in this thesis. Neither the thesis nor substantial extracts from it may be printed or otherwise reproduced without the author's permission.
AVIS:

L'auteur a accordé une licence non exclusive permettant à la Bibliothèque et Archives Canada de reproduire, publier, archiver, sauvegarder, conserver, transmettre au public par télécommunication ou par l'Internet, prêter, distribuer et vendre des thèses partout dans le monde, à des fins commerciales ou autres, sur support microforme, papier, électronique et/ou autres formats.

L'auteur conserve la propriété du droit d'auteur et des droits moraux qui protège cette thèse. $\mathrm{Ni}$ la thèse ni des extraits substantiels de celle-ci ne doivent être imprimés ou autrement reproduits sans son autorisation.
In compliance with the Canadian

Privacy Act some supporting forms may have been removed from this thesis.

While these forms may be included in the document page count, their removal does not represent any loss of content from the thesis.
Conformément à la loi canadienne sur la protection de la vie privée, quelques formulaires secondaires ont été enlevés de cette thèse.

Bien que ces formulaires aient inclus dans la pagination, il n'y aura aucun contenu manquant.

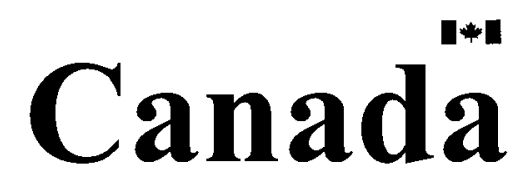




\section{Abstract}

This research examines the investments in open source software made by 12 large computer and telecommunication companies listed in the NASDAQ and identifies the factors that drive these investments. Companies in the sample are classified into five categories based on the volume and diversity of their investments in open source and a model for the relationship between antecedent factors and investment aggressiveness is developed. Results suggest that five key factors drive large companies to invest in open source software: degree to which users perceive the open source software as better than alternatives, use of open source software for internal product development, savings from using open source software, top management team's support for open standards, and revenue from new product-markets. Senior executives and industry analysts will be interested in the way open source software investment aggressiveness was operationalized and academics will benefit from the concrete examples of three types of investments in open source made by large companies. 


\section{Acknowledgement}

This thesis was developed as part of the Competing in open environments research program led by Tony Bailetti, Carleton University, and Peter Carbone, Nortel. The support received from Nortel for this research and the M. Eng. in Telecommunications Technology Management program is gratefully acknowledged.

I greatly acknowledge my thesis supervisor Professor Tony Bailetti for his tireless guidance, encouragement and support throughout this study. I also appreciate Professor Bailetti for always encouraging and challenging me to reach my best throughout my academic program.

I would like to express my appreciation to Professor John Callahan for his generous comments and constructive suggestions at various stages of my work.

I thank my family for their unconditional love and continuous encouragement throughout this study, and for supporting me to pursue my interests. 


\section{Table of Contents}

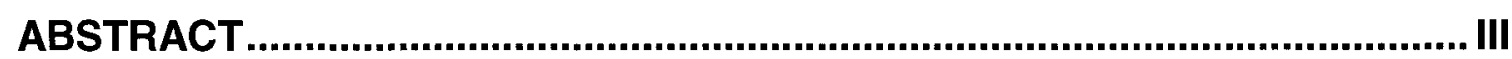

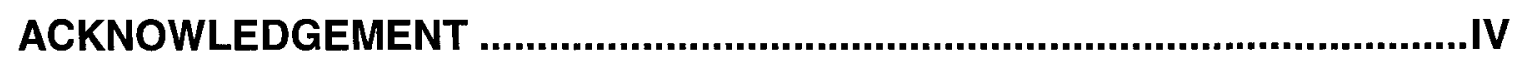

TABLE OF CONTENTS ....................................................................................

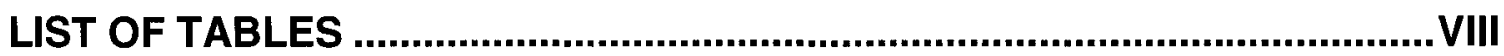

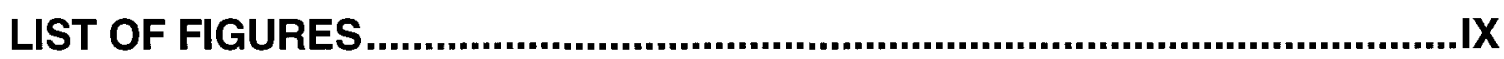

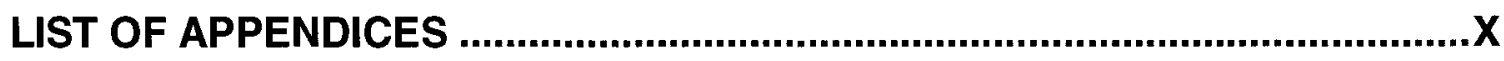

1. INTRODUCTION .............................................................................................. 1

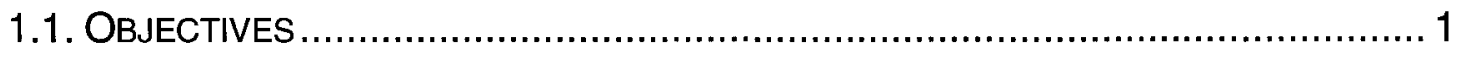

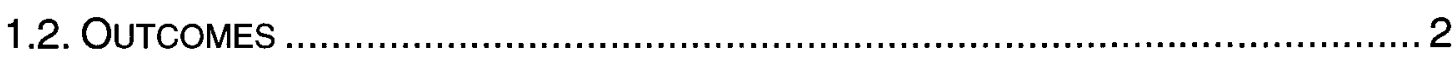

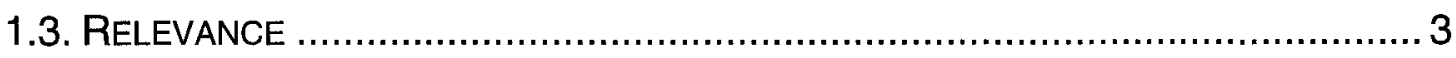

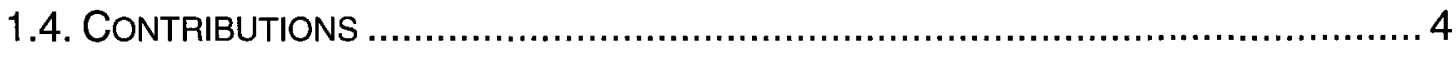

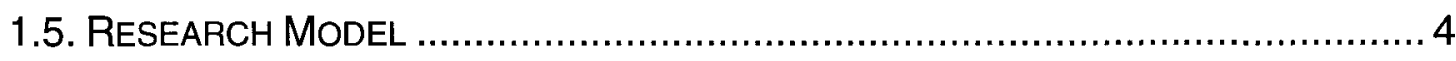

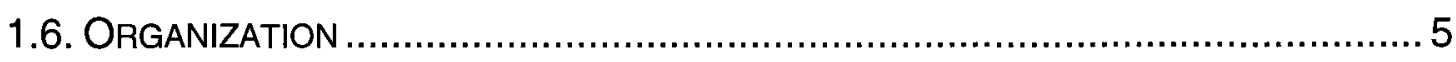

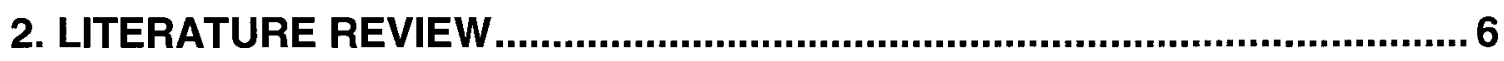

2.1. THE CoMPETITIVE AgGRESSIVENESS OF COMPANIES ................................ 6

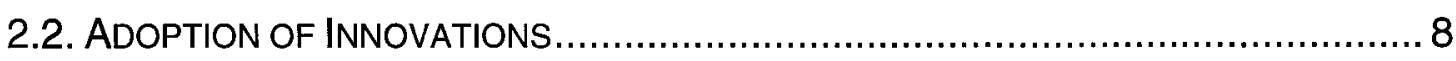

2.3. Organization Adoption ANd Open SouRce ........................................ 13

2.3.1. OSS Incorporated as Platforms, Standards and COTS................... 13 
2.3.2. Gift Economy of OSS and Its Commercialization Models 18

2.3.3. Benefits, Risks, and Motivations for Companies to Participate in OSS

Development 22

2.4. LESSONS LEARNED FROM THE LITERATURE REVIEW 29

3. RESEARCH METHOD 31

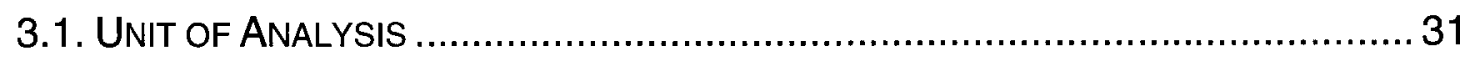

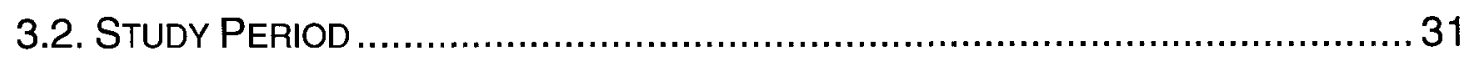

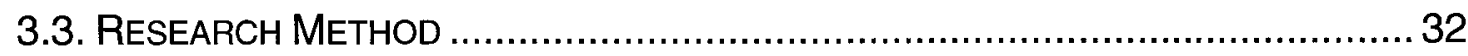

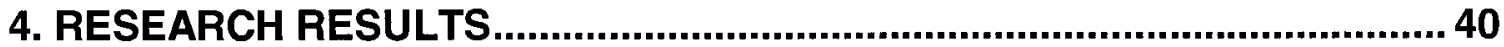

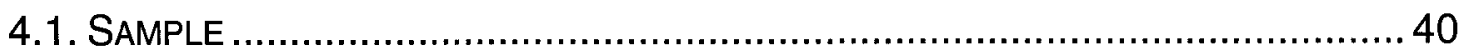

4.2. VOLUME AND DIVERSITY OF INVESTMENTS IN OSS .................................... 41

4.3. Factors that AfFect OSS INVESTMENT AggReSSIVENESS......................47

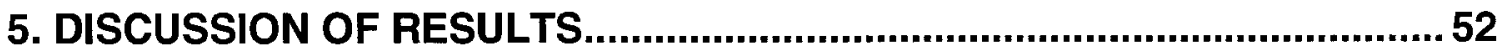

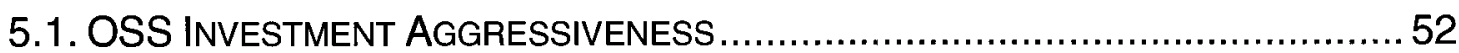

5.2. FACTORS THAT DRIVE OSS INVESTMENT AGGRESSIVENESS ..........................53

5.3. Factors IdENTIFIEd AND Product DeVELOPMENT DeCISIONS .....................58

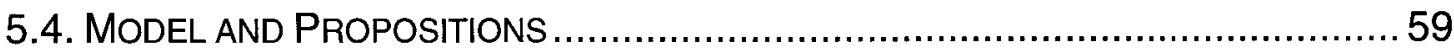

6. CONCLUSIONS, LIMITATIONS, AND SUGGESTIONS FOR FUTURE

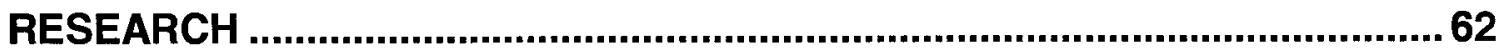

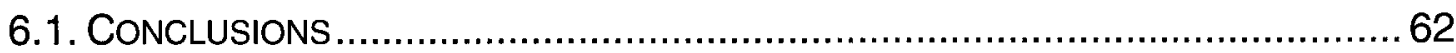

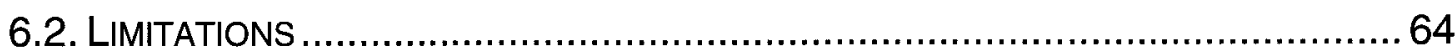

6.3. SUGGESTIONS FOR FUTURE RESEARCH ................................................. 64 


\section{List of Tables}

Table 1: Factors that Affect the Adoption of Innovations ...........................12

Table 2: Means of Appropriating Returns and Protection ..........................20

Table 3: Seven Open Source Business Strategies for Competitive

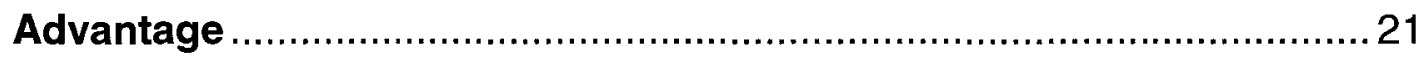

Table 4: Benefits for Companies Contributing to OSS …............................23

Table 5: Risks of Companies Contributing to OSS …..............................26

Table 6: Taxonomy of Motivations for Firms to Participate in OSS

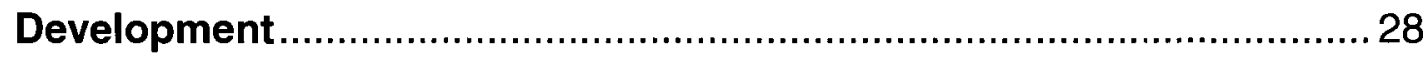

Table 7: 12 Companies in the Sample ………........................................ 41

Table 8: Number of Investments in the Sample ........................................ 41

Table 9: Volume and Diversity of OSS Investments Made by Companies in

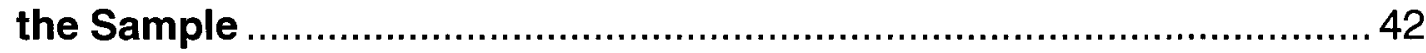

Table 10: Companies Categorized in Terms of their OSS Investment

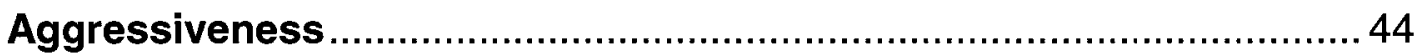

Table 11: Count of the Factors Companies Stated Drive their Investments in OSS

Table 12: Factors that Drive Investments in OSS .......................................5

Table 13: OSS Investments Related to the Nokia $770 \ldots \ldots \ldots \ldots \ldots \ldots \ldots \ldots \ldots \ldots \ldots \ldots \ldots \ldots \ldots \ldots \ldots \ldots \ldots . . . .55$

Table 14: OSS Investments Related to Novell NetWare .............................56

Table 15: OSS Investments for Linux in HP .............................................5 


\section{List of Figures}

Figure 1: Research Model ........................................................ 5

Figure 2: Drivers and Consequences of Competitive Aggressiveness ........ 7

Figure 3: Antecedents of Option Value in IT Platform Investments............11

Figure 4: Volume and Diversity of Four Companies in Category 1 ............ 45

Figure 5: Volume and Diversity of Eight Companies Not in Category $1 \ldots . . .46$

Figure 6: Factors that Drive Large Companies to Invest in OSS...............60

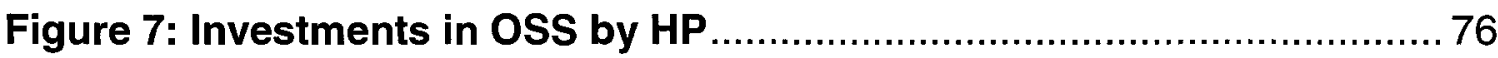

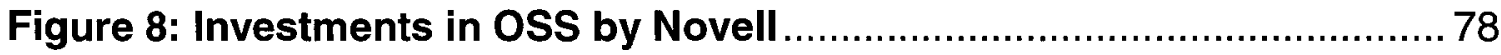

Figure 9: Investments in OSS by Sun ............................................ 80

Figure 10: Investments in OSS by Symantec/VERITAS ......................... 82

Figure 11: Investments in OSS by Nokia ..................................... 84

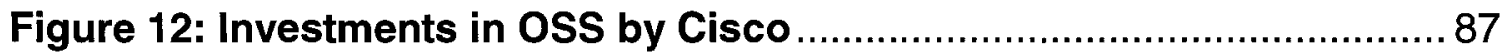

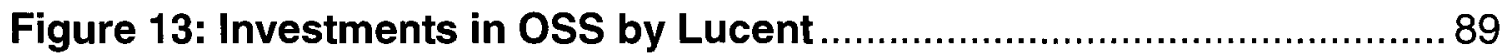




\section{List of Appendices}

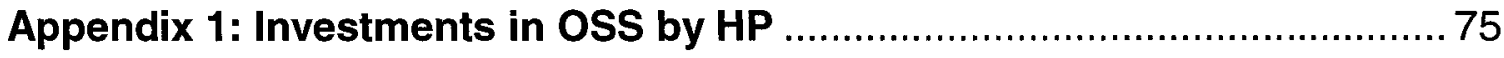

Appendix 2: Investments in OSS by Novell........................................... 77

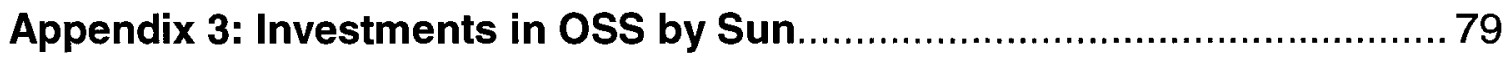

Appendix 4: Investments in OSS by Symantec/VERITAS ............................ 81

Appendix 5: Investments in OSS by Nokia.............................................. 83

Appendix 6: Investments in OSS by Other Communication Equipment

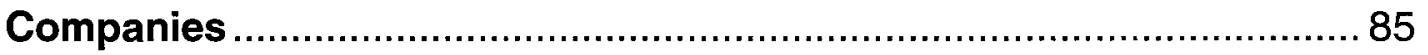

Appendix 7: Investments in OSS by Networking and Communication

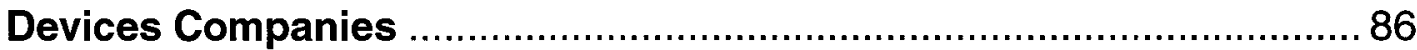

Appendix 8: Investments in OSS by Processing Systems Products

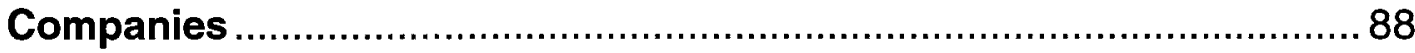

Appendix 9: Factors of Type A Found in Data (84 projects) .......................90

Appendix 10: Factors of Type B Found in Data (73 projects) ..................... 91

Appendix 11: Factors of Type C Found in Data (9 projects) ...................... 92 


\section{Introduction}

\subsection{Objectives}

The objective of this research is to examine the investments that large computer and telecommunication companies make in open source software (OSS) and the factors that affect a large company's investment in OSS. This research answers two questions:

1. Which large computer and telecommunication companies are more aggressive than others in terms of their investments in OSS?

2. What are the factors that drive a large computer or telecommunication company to invest in OSS?

The conceptualization of OSS investment profile and the definitions of volume and diversity used in this research build on the competitive aggressiveness literature (Ferrier, 2001). For the purposes of this research, a company's OSS investment profile is an ordered sequence of events each anchored around an investment in open source software. Each event is an observable competitive move initiated by a firm to enhance its competitive position (Ferrier, Smith, \& Grimm, 1999; Ferrier, 2001). 
Investment events are organized into three categories:

A. Release of proprietary code to an OSS project

B. Funding or assigning one or more development teams to an existing OSS project

C. Purchasing or investing in an OSS company - a company that supplies OSS products and services (Rossi \& Bonaccorsi, 2005)

A company's OSS investment profile is conceptualized as having two dimensions: volume and diversity. Volume is the total number of investment events.

Companies that carry out more investments in OSS are more OSS investment aggressive than firms that make a small number of investments. Diversity is defined as the extent to which the sequence of investment events is comprised of investments of many different types. Companies that carry out all three types of investments are more OSS investment aggressive than companies that carry out a single type of investment.

\subsection{Outcomes}

The outcomes of this research are:

1. OSS investment profiles including volume and diversity for 12 large computer and telecommunication companies

2. Factors that affect a large company's OSS investment aggressiveness 
3. Propositions that describe the relationship between antecedent factors and OSS investment aggressiveness

\subsection{Relevance}

This research is relevant for at least three reasons. First, top management teams of large firms and industry analysts will be interested in ways to operationalize aggressiveness using data that is publicly available in the context of OSS.

Second, academics studying technology adoption in general and OSS adoption in particular will be interested in concrete examples of investments in OSS made by large companies and testing the propositions developed in this research.

Third, top management teams of suppliers to large firms will be interested in identifying new business opportunities opened up by large firms making OSS investments. Suppliers can adjust their business and product strategies to complement the business and product strategies of large companies investing in OSS. 


\subsection{Contributions}

This research makes at least two contributions. First, this research identifies the factors that motivate large computer and telecommunication companies to invest in OSS. Thus, it contributes to the innovation adoption literature.

Second, this research builds on the competitive aggressiveness literature to identify companies that are more aggressive than others in terms of their OSS investments.

\subsection{Research Model}

Figure 1 illustrates the research model. The model was adapted from the one used by Ferrier (2001). The shaded area illustrates that the focus of this research is on the factors that affect open source aggressiveness. The purpose was not to relate open source aggressiveness to company performance. Thus, companies' financial data and how these data related to OSS investments were not examined. Moreover, the financial returns to OSS investments of types A, B and C were not examined. 


\section{Figure 1: Research Model}

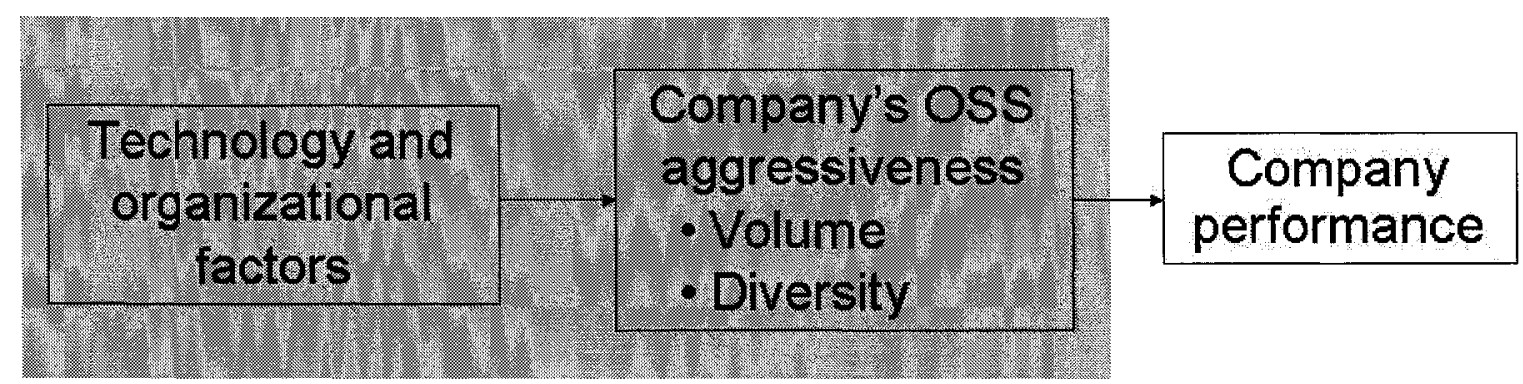

\subsection{Organization}

The rest of this thesis is organized as follows. The second chapter provides the literature review. The third chapter provides the research method that will be used for this research. Chapter 4 provides the results of the research. Chapter 5 discusses the results of the research. Chapter 6 provides the conclusions, limitations, and suggestions for future research. 


\section{Literature Review}

This chapter is organized into four sections. The first section reviews the literature regarding competitive aggressiveness. The second section reviews the reasons that companies give when making adoption decisions. The third section reviews the literature of OSS. Lastly, the fourth section provides a summary of important lessons learned from the literature review.

\subsection{The Competitive Aggressiveness of Companies}

By defining strategy as a sequence of competitive actions carried out over time, Ferrier (2001) develops and tests a dynamic process model of competitive interaction among firms. His research suggests that a firm's sequence of competitive actions is influenced by top management team diversity, past performance, slack, and important industry characteristics. Figure 2 illustrates Ferrier's research model.

Six categories of competitive actions are used in Ferrier's research. They are pricing actions, marketing actions, new product actions, capacity-related actions, service actions, and overt signaling actions. 
Ferrier states that a sequence of competitive actions has the following dimensions: volume, duration, complexity, and unpredictability. Among those dimensions, volume can be defined as the number of action events that make up the strategy and complexity is defined as the extent to which all possible types of action events are represented in the strategy (Ferrier, 2001).

Figure 2: Drivers and Consequences of Competitive

\section{Aggressiveness}

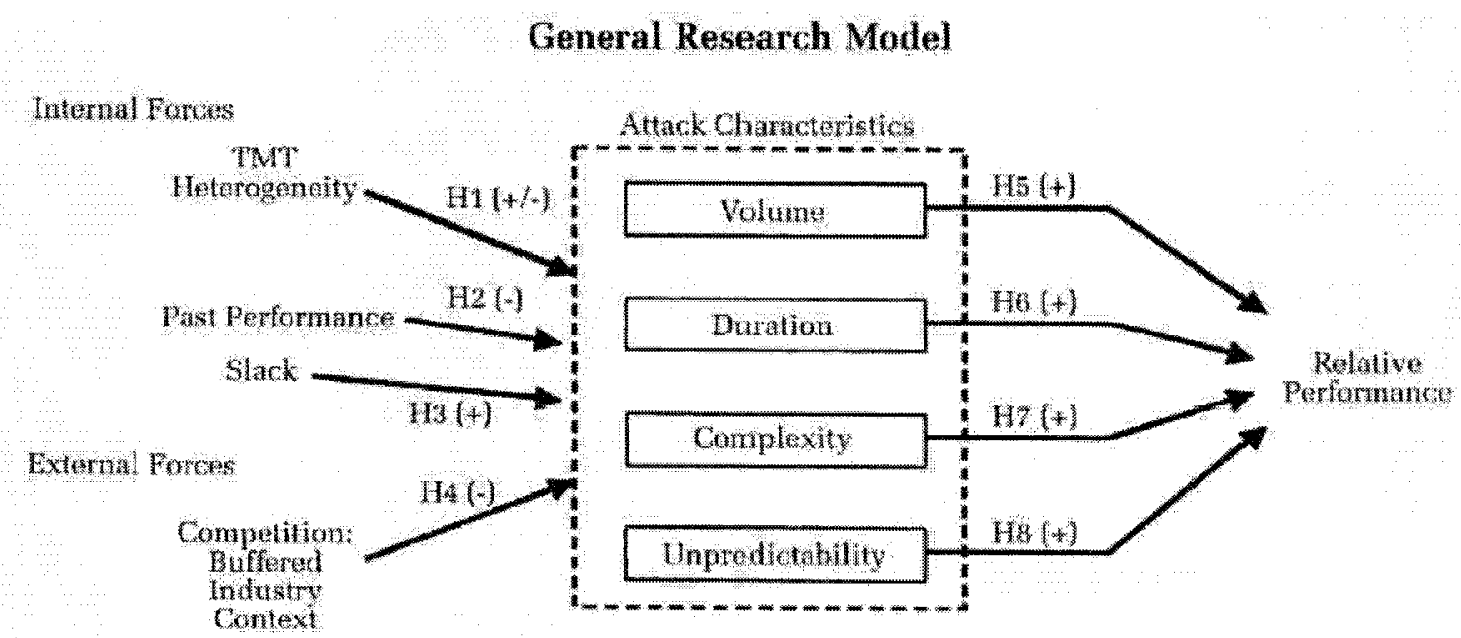

Source: Ferrier, W. J. 2001. Navigating the competitive landscape: the drivers and consequences of competitive aggressiveness. Academy of Management Journal, 44(4): 858-877. 


\subsection{Adoption of Innovations}

\section{Factors Found from the Diffusion of Innovations}

DiPietro, Wiarda and Fleischer (1990) define a "context for change" consisting of three elements: technology, organization, and environment. These three elements (cited in subsequent research via the acronym "TOE") are posited to interact with each other and to influence decisions about technological innovation (Tornatzky \& Fleischer, 1990: 153). The TOE framework as originally presented, and later adapted in information technology adoption studies, is a useful analytical tool for distinguishing between inherent qualities of an innovation itself and the motivations, capabilities, and broader environmental context of adopting organizations (Dedrick \& West, 2004).

The theoretical foundation for most technology adoption research is found in the diffusion of innovation literature (Tornatzky \& Klein, 1982; Rogers, 1983, 1995, 2003). This literature studies the process of technology diffusion and the factors influencing technology adoption decisions. Tornatzky and Klein (1982) present a process view that moves from research and development to deployment, adoption, implementation and routinization. Technology developers (or producers) carry out research, development and deployment activities, while technology users carry out adoption, implementation and routinization activities. Rogers focuses on the adoption process itself. According to the point in time at 
which users adopt the innovation, Rogers classifies them from innovators to early adopters, early majority, late majority and laggards.

A major stream in diffusion of innovation literature theorizes about the characteristics of innovations that influence whether - and at what rate - such innovations are adopted. Rogers lists five technology characteristics that influence the adoption decision: relative advantage, compatibility, complexity, trialability, and observability. Tornatzky and Klein (1982) concluded that three of these variables were consistently linked to technology adoption: compatibility, relative advantage, and complexity. Compatibility with existing technologies and relative advantage over current technologies were positively related to adoption, while technological complexity was negatively related to adoption.

\section{Factors Found from Standards Adoption Studies}

When considering standards adoption, barriers to adoption have been previously classified in economics research under the category of "switching costs" (Dedrick \& West, 2004). Von Weizsäcker (1984) modeled how users would consider the present net value of anticipated future switching costs in technology adoption. Klemperer (1987) classified switching costs into three categories: transitory transaction costs, learning costs (e.g., worker skills), and contractual costs (e.g., contract termination penalties) that were deliberately introduced by vendors to build barriers for subsequent competitors. 
The other hypothesized factor in the economics of standards adoption is the role of positive network effects that accrue to all adopters of a popular standard. Katz and Shapiro (1985) showed how indirect network effect - the availability of software to support a given hardware standard - would make the popular standard more attractive to future adopters. Consumers or the producer of the good may capture these benefits or the benefits may spill over to society at large. Brynjolfsson and Kemerer (1996) provided evidence that user compatibility with the most common spreadsheet standard had a statistically significant and positive effect.

\section{Adoption Factors from Real Option Analysis}

Figure 3 presents a model of the determinants of option value in innovative information technology platform investments. The model is based on the Real Option Analysis (ROA) developed by Fichman (2004). The model creates a synthesis of work on real options and technology adoption. Fichman argued that companies who recognize the potential option value for information technology platforms will be more likely to initiate adoption of those platforms through technology positioning investments. From four complimentary perspectives on organizational innovation, such as: (1) technology strategy, (2) organizational learning, (3) innovation bandwagons, and (4) technology adaptation, 12 factors that have a clear economic interpretation from a real options perspective are identified. The 12 factors are technology radicalness, knowledge barriers, susceptibility to network externalities, prospects for dominance of the technology 
class and instance, interpretive flexibility, divisibility, strategic importance of affected processes, sustainability of advantage, innovative capabilities, learningrelated endowments, and contributions to exploitable absorptive capacity.

\section{Figure 3: Antecedents of Option Value in IT Platform}

\section{Investments}

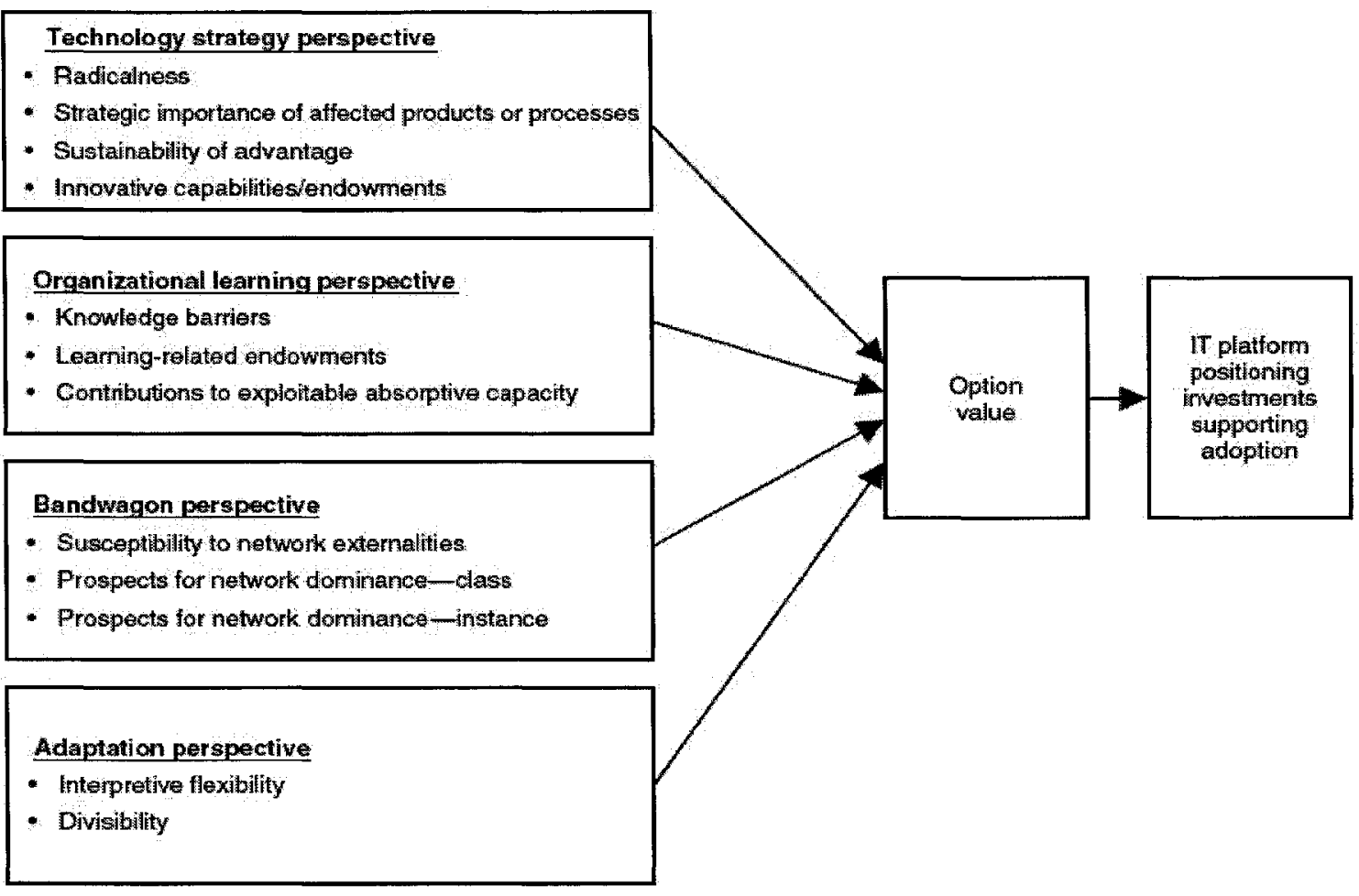

Source: Fichman, R. G. 2004. Real Options and IT Platform Adoption:

Implications for Theory and Practice. Information Systems Research, 15(2):132154. 
Table 1 lists the factors that affect the adoption of innovations in companies that were identified from literature reviewed.

Table 1: Factors that Affect the Adoption of Innovations

\begin{tabular}{|c|c|c|c|c|}
\hline \multirow[t]{2}{*}{ Context } & \multicolumn{3}{|c|}{ Relevant Theoretical Concept } & \multirow[t]{2}{*}{ Reference } \\
\hline & DOI & Standard & ROA & \\
\hline Technology & $\begin{array}{l}\text { Relative advantage } \\
\text { Compatibility } \\
\text { Complexity, } \\
\text { Trialability } \\
\text { Observability } \\
\text { Availability }\end{array}$ & $\begin{array}{l}\text { Switching } \\
\text { cost } \\
\text { Network } \\
\text { effects }\end{array}$ & $\begin{array}{l}\text { Radicalness } \\
\text { Knowledge barriers } \\
\text { Susceptibility to network } \\
\text { externalities } \\
\text { Prospects for dominance of } \\
\text { the technology class and } \\
\text { instance } \\
\text { Interpretive flexibility } \\
\text { Divisibility }\end{array}$ & $\begin{array}{l}\text { Tornatzky \& } \\
\text { Klein, 1982; } \\
\text { Rogers, } \\
\text { 1983, 1995, } \\
\text { 2003; } \\
\text { Tornatzky \& } \\
\text { Fleischer, } \\
\text { 1990; } \\
\text { von }\end{array}$ \\
\hline Organization & $\begin{array}{l}\text { Organization } \\
\text { structures } \\
\text { Communication } \\
\text { process } \\
\text { Top management } \\
\text { leading behavior } \\
\text { Organization size } \\
\text { Slack resources }\end{array}$ & & $\begin{array}{l}\text { Strategic importance of } \\
\text { affected processes } \\
\text { Sustainability of advantage } \\
\text { Innovative capabilities } \\
\text { Learning-related } \\
\text { endowments } \\
\text { Contributions to exploitable } \\
\text { absorptive capacity }\end{array}$ & $\begin{array}{l}\text { Weizsäcker, } \\
\text { 1984; } \\
\text { Klemperer, } \\
\text { 1987; } \\
\text { Brynjolfsson } \\
\text { \& Kemerer, } \\
\text { 1996; } \\
\text { Katz \& }\end{array}$ \\
\hline Environment & $\begin{array}{l}\text { Industry characteristics } \\
\text { and market structure } \\
\text { Technology support } \\
\text { infrastructure } \\
\text { Government regulation }\end{array}$ & $\begin{array}{l}\text { Network } \\
\text { effects } \\
\text { Switching } \\
\text { cost } \\
\text { Sponsorship }\end{array}$ & & $\begin{array}{l}\text { Shapiro, } \\
1985 ; \\
\text { Fichman, } \\
2004 \\
\text { Dedrick \& } \\
\text { West, } 2004\end{array}$ \\
\hline
\end{tabular}




\subsection{Organization Adoption and Open Source}

\subsubsection{OSS Incorporated as Platforms, Standards and COTS}

\section{OSS Incorporated as Platforms and Standards}

Companies in many industries are considering platform-based product development in their quest to manage the complexity of offering greater product variety (Krishnan \& Gupta, 2001). Product platforms, which are component and subsystem assets shared across a product-family, enable a firm to better leverage investments in product design and development. While the platform approach offers a number of benefits, it also imposes certain additional costs. A firm's product positioning and introduction sequence decisions made during the product-planning phase are significantly impacted by the presence of platforms. Specifically, a platform increases the separation among products and offers a multitude of product introduction strategies. Also, platforms are not appropriate for extreme levels of market diversity or high levels of non-platform scale economics. (Krishnan \& Gupta, 2001)

Dedrick and West (2004) developed a grounded theory of open source platform adoption and explored the complex adoption decisions made by organizations. Their research focused on computing platform standards as defined by operating systems and computer hardware, specifically among competing server platforms. 
They documented a rich set of technological, organizational and environmental factors that may have influenced making decisions on OSS platform.

These factors are:

- Technological factors: hardware and software cost, reliability, availability of third party applications, portability of own applications, skills of existing IT workers, fit to task, difficulty in administration, and ease of experimenting

- Organizational factors: IT capital budget, IT staff time, innovativeness of IT organization, worker experience with a new platform

- Environmental factors: industry maturity, availability of skilled IT workers, availability of external support services, platform long-term viability

For technology users, standard adoption decisions have important consequences. Adopting a winning standard enables users to benefit from a sustained stream of producer investment in the technology and access to a large supply of complementary assets investment (Farrell \& Saloner, 1988; Katz \& Shapiro, 1985). By contrast, adopters of a losing standard face the likelihood of eventually having to switch to the winning standard or living with a much smaller supply of complementary assets and levels of producers (Dedrick \& West, 2004).

Most projects adopt at least one well-established design architecture or technology (Torchiano \& Morisio, 2004). Problems arise when the architecture's 
components do not fully or correctly support the standards or when different components support different and incompatible versions of a standard. On the other hand, reusing a well-established architecture is a success factor for the projects. Although requirements are important, the architecture really drives the selection process and was the pivot of all trade-off activities in practice (Torchiano \& Morisio, 2004).

\section{OSS Incorporated as COTS}

Many efforts now focus on integrating off-the-shelf software packages to achieve particular software implementation goals (Torchiano \& Morisio, 2004). Many requirements must be considered when choosing a suitable software package, regardless of whether the candidate is OSS or commercial. Some important adoption criteria do not distinguish between OSS and commercial-software candidates: functional capability, efficiency, speed of execution, and organizational standards and preferences (Torchiano \& Morisio, 2004).

Some researches suggest that open source products are usually considered to be completely different from closed-source products in projects which used OSS or free-software products (Lawton, 2002). Architectural mismatch is one of the primary sources of integration problems (Egyed et al., 2000; Yakimovich et al., 1999). Integration problems result from lack of compliance with standards whereas architectural mismatches constitute a secondary issue. The selected COTS product lacks only a few required functions. One of the most common 
remedial solutions among interviewees in such a case is to add custom codes to the components to provide the missing functions. This type of code can be called "addware." The literature greatly emphasizes the integration aspects of custom code (often called "glueware") (Basili \& Boehm, 2001; Morisio et. al., 2000; Boehm \& Abts, 1999). Formalizing the selection process for COTS products has sparked a great interest in the past few years. Researchers have proposed several structured, formal, or semiformal selection procedures (Lawlis et al., 2001). For COTS products selection, some researchers propose a process based largely on requirements and their negotiation (Lawlis et al., 2001; Boehm, 2000). Published studies generally describe the lack of control over the features and evolution of COTS products as an immutable condition that integrators must tolerate (Basili \& Boehm, 2001; Boehm \& Abts, 1999).

It seems, however, that those studies disagree, lack product and project details, and are founded on uncritically accepted assumptions (Torchiano \& Morisio, 2004). Open source software is often used as closed source and projects use custom code more often as addware. Developers seldom use formal selection procedures and familiarity with either the product or the generic architecture is the leading factor in selection. Integrators tend to influence the vendor on product evolution whenever possible (Torchiano \& Morisio, 2004). 


\section{Risks of Using OSS in Product Development}

Industry is increasingly using open source building blocks for mature technologies such as operating systems, middleware, databases, protocol stacks, and development environments. Mature OSS components often offer a more permanent solution than commercial ones, especially in times of economic uncertainties and small suppliers (Ruffin \& Ebert, 2004). They typically provide independence from a specific supplier, long-term support at affordable costs, low cost of ownership because of shared resources, and intrinsic effects such as greater availability of skills or engineering motivation (Ruffin \& Ebert, 2004).

Ruffin and Ebert (2004) discussed the major legal aspects and risks of using OSS and how to mitigate them in product development. Depending on the product, its usage, and the market constraints, they listed eight specific properties that can be advantageous of OSS. Ruffin and Ebert also stated three major risks when companies integrate OSS directly into a product as source code. Those risks are:

- The use of OSS code will fail to comply with the OSS license terms.

- The infringement of third parties' patents or other intellectual-property rights.

- The use of OSS tools in development will fail to give the copyright holder certain rights 
Ruffin and Ebert (2004) argue that companies need to introduce explicit checks in the decision-making processes across a product's life cycle.

Paulson, Succi and Eberlein (2004) made an empirical study of open-source and closed-source software projects to quantitatively investigate and validate common perceptions about open-source projects. Their research found that OS projects did not exhibit significantly higher growth rates over time than closed source projects. In their analysis, closed source projects were generally simpler than the OS projects. The idea that an OS project is more modular than a closed source project was not supported either. They concluded that practitioners should ensure that an appropriate metrics collection strategy should be in place to verify the perceived benefits, when implementing or switching to the open source development model.

\subsubsection{Gift Economy of OSS and Its Commercialization Models}

A variety of open source strategies have been employed by some companies to seek new market opportunities. Gift economy in open source provides some insights as to why companies would like to give away their code, and what companies would expect to get back from this gift (Gabriel \& Goldman, 2002). Other studies on the use of open source strategies can provide insights into how companies are making money using open source and what are key factors (e.g. 
layer of a software stack, licensing, services or technical support) when using open an source strategy appropriately. (Dahlander, 2004; Koenig, 2004)

By opening up part of a company to the outside, the company can provide gifts that trigger the gift-economy effect, technology; tools, and prototypes that are of high value to outside companies and organizations (Gabriel \& Goldman, 2002).

Table 2 lists the possible approaches to appropriate adequate returns and a frame for analyzing the means by which firms can protect their knowledge from Dahlander's research (2004). Forced by the value appropriation issues and changing environment, the firms try a variety of approaches to create revenue. Those firms face the challenge of important resources, which provide competitive products and services, being located outside the boundary of the firm. 
Table 2: Means of Appropriating Returns and Protection

\begin{tabular}{|c|c|c|}
\hline Category & Sub-categories & Explanation of how it works in OSS \\
\hline \multicolumn{3}{|c|}{ Means of Appropriating Returns } \\
\hline Products & Licensing & $\begin{array}{l}\text { Licensing the right to use the software i.e. adding a proprietary } \\
\text { part to the open code or by allowing the customer to use the } \\
\text { source code how they wish }\end{array}$ \\
\hline \multirow{4}{*}{ Services } & Black-box & Bunching several pieces of OSS in a hardware solution \\
\hline & Consultancy & $\begin{array}{l}\text { Consultancy work based on an area of expertise, be it a } \\
\text { product that the firm release or a community established } \\
\text { project }\end{array}$ \\
\hline & Education & $\begin{array}{l}\text { Education based on an area of expertise, be it a product that } \\
\text { the firm release or a community established project }\end{array}$ \\
\hline & Support & $\begin{array}{l}\text { Support based on an area of expertise, be it a product that the } \\
\text { firm release or a community established project }\end{array}$ \\
\hline \multicolumn{3}{|c|}{ Means of Protections } \\
\hline $\begin{array}{l}\text { Intellectual } \\
\text { property rights } \\
\text { (IPR) }\end{array}$ & Patents, copyright & $\begin{array}{l}\text { Institutional protection in terms of temporary monopoly granted } \\
\text { to novel, useful and non-obvious innovations } \\
\text { Institutional protection that grant creators exclusive right to } \\
\text { reproduce, prepare derivative works, distribute, perform and } \\
\text { display the work publicly }\end{array}$ \\
\hline Secrecy & & Keeping secrets within the firm, primarily by closing the code \\
\hline $\begin{array}{l}\text { First-mover } \\
\text { advantages }\end{array}$ & $\begin{array}{l}\text { Network externalities, } \\
\text { first-mover advantages }\end{array}$ & $\begin{array}{l}\text { Early entry to the market which can create advantages by } \\
\text { acquire superior resources and capabilities }\end{array}$ \\
\hline $\begin{array}{l}\text { Complementary } \\
\text { assets }\end{array}$ & & $\begin{array}{l}\text { Getting a large user base } \\
\text { Using complementary assets such as distribution, marketing in } \\
\text { conjunction with the innovation }\end{array}$ \\
\hline
\end{tabular}

Source: Dahlander, L. 2004. Appropriating returns from open innovation

processes: A multiple case study of small firms in open source software. Working

Paper, Department of Industrial Dynamics School of Technology Management

and Economics, Chalmers University of Technology. 


\section{Table 3: Seven Open Source Business Strategies for}

Competitive Advantage

\begin{tabular}{|l|l|}
\hline \multicolumn{1}{|c|}{ Strategies } & \multicolumn{1}{|c|}{ Brief description } \\
\hline Optimization Strategy & $\begin{array}{l}\text { One layer of a software stack is "modular and conformable," } \\
\text { allowing adjacent software layers to be "optimized" }\end{array}$ \\
\hline Dual License & $\begin{array}{l}\text { Offering free use of its software with some limitations, or } \\
\text { alternatively offers for a fee commercial distribution rights and a } \\
\text { larger set of features. }\end{array}$ \\
\hline Consulting Strategy & $\begin{array}{l}\text { Providing enterprise integration consulting for popular open } \\
\text { source software }\end{array}$ \\
\hline Subscription Strategy & $\begin{array}{l}\text { Subscription entitling the maintenance, configuration support } \\
\text { and updates and upgrades to the technology }\end{array}$ \\
\hline Patronage Strategy & $\begin{array}{l}\text { Commoditizing a particular layer of the software stack, } \\
\text { eliminating competitors that are extracting revenue from that } \\
\text { layer }\end{array}$ \\
\hline Hosted Strategy & $\begin{array}{l}\text { Hosted service companies using OSS as a cornerstone to their } \\
\text { IT platforms }\end{array}$ \\
\hline implemented platform with minimal capital outlay
\end{tabular}

Source: Koenig, J. 2004. Seven open source business strategies for competitive advantage. IT Manager's Journal, May 14. 
Table 3 lists seven open source business strategies for competitive advantage. Open source provides a powerful tool for aiming a business towards a faster revenue trajectory, for improving value, and for out-maneuvering the competition (Koenig, 2004). Seven different business strategies that can give the hardware and software vendors, and vendors of complementary or substitute services competitive advantages are provided in Koenig's article. Companies should understand open source business strategies and determine which strategies are useful for them to adopt.

\subsubsection{Benefits, Risks, and Motivations for Companies to Participate in OSS Development}

\section{Benefits for Companies to Participate in OSS Development}

Table 4 lists the benefits for firms for contributing to OSS in Henkel's research (2004). He classified companies engaging in OSS projects into two groups: companies turning proprietary software into OSS and companies contributing to existing OSS.

For both groups, one of the biggest potential benefits from contributing to open source software is that outside parties joined in the collaborative development of the software (Bonaccorsi \& Rossi, 2003; Gabriel \& Goldman, 2002; Henkel, 2004). By engaging in OSS, companies receive feedback and advice regarding OSS design, direction of pursuit, new features and usability, and help with 
implementation (Goldman \& Gabriel, 2002). Companies can lower software development and R\&D costs, improve their software, and develop commercial solutions through the feedback and contributions (the bug fixing activities) from the open source community (Bonaccorsi \& Rossi, 2003). Companies can also receive development support from other firms, from external developers, or from users in order to improve the popularity and quality of the open source products (Bonaccorsi \& Rossi, 2003; Goldman \& Gabriel, 2002; Henkel, 2004).

\section{Table 4: Benefits for Companies Contributing to OSS}

\begin{tabular}{|c|c|c|c|}
\hline & All contributors & Specific to users & $\begin{array}{l}\text { Specific to sellers of } \\
\text { complement. }\end{array}$ \\
\hline Benefits & $\begin{array}{l}\text { Improvement by others } \\
\text { Reduced maintenance cost } \\
\text { Programming discipline } \\
\text { Standard setting } \\
\text { GPL-ed OSS can be used } \\
\text { Attraction for programmers } \\
\text { Reputational gains } \\
\text { - Technical skills } \\
\text { - "Good OS citizen" }\end{array}$ & $\begin{array}{l}\text { Decreased dependency } \\
\text { on proprietary software }\end{array}$ & $\begin{array}{l}\text { Increased sales of } \\
\text { complementary goods } \\
\text { Pricing pressure on } \\
\text { competitors }\end{array}$ \\
\hline
\end{tabular}

Source: Henkel, J. 2004. Open source software from companies - tools, complements, and collective invention. Zeitschrift für Betriebswirtschaft, Supplement 4, 1-23. 
Another possible benefit pursued by companies contributing to OSS development is setting a standard (Henkel, 2004). This is particularly important for software related to infrastructure and tools (Raymond, 2001). OSS is of interest to a large share of the market and may exert network externalities that drive the establishment of a standard (Henkel, 2004; Goldman \& Gabriel, 2002; Koenig, 2004). Releasing code as open source increases the likelihood that what is proposed as the standard will be adopted (Goldman \& Gabriel, 2002). Some OSS projects have a standard development goal such as API definitions, language extensions, or tool extensions.

Henkel (2004) also argued that companies contributing to OSS development need to appear as a "good citizen" in the open source community. They may release high quality OSS to improve the company's technical reputation.

There have been a number of business models that are or could be built around OSS (Raymond, 2001; Hecker, 1999; Koenig, 2004). Most of the models imply that the respective firm develops OSS, while making money selling products and services in complementary market segments to such OSS (Henkel, 2004; Lerner \& Tirole, 2004). This strategy will make sense when the profit increase in the complementary segment offsets the profit decrease in the primary segment (Lerner \& Tirole, 2002a). 
Companies may benefit from weakening competitors or decreasing dependency on suppliers by contributing to OSS development (Henkel, 2004; Koenig, 2004;

Lerner \& Tirole, 2002a). Releasing code as OSS helps the company effectively pursue new markets and puts pricing pressure on competitors (Henkel, 2004; Koenig, 2004). A company may also commoditize a particular layer of the software stack and eliminate competitors that are extracting revenue from that layer (Koenig, 2004).

\section{Risks for Companies to Participate in OSS Development}

Table 5 lists the risks of contributing to OSS for firms in Henkel's research (2004). To all commercial companies contributing to OSS, an obvious risk of putting software into open source is that they may lose most intellectual property rights to it (Gabriel \& Goldman, 2002; Henkel, 2004). If selling such software is an option, then the profit from selling must be trade-off against the benefits of open-sourcing (Henkel, 2004). Another risk lays in the fact that if a company wants the released OSS to yield stronger benefits to itself with good publicity, the company needs to be well prepared for the release (forking risk) and provide maintenance for such OSS, which could cause cost to the company (Henkel, 2004). 


\section{Table 5: Risks of Companies Contributing to OSS}

\begin{tabular}{|c|l|l|l|}
\hline & \multicolumn{1}{|c|}{ All contributors } & Specific to users & $\begin{array}{l}\text { Specific to sellers } \\
\text { of complement. }\end{array}$ \\
\hline \multirow{2}{*}{ Risks/ } & $\begin{array}{l}\text { Loss of intellectual property } \\
\text { Cost of maintaining OS }\end{array}$ & $\begin{array}{l}\text { Loss of competitive advantage } \\
\text { Insights for competitors into }\end{array}$ & Loss of sales \\
downside & Project (for maintainer) & business processes & \\
& Forking & & \\
\hline
\end{tabular}

Source: Henkel, J. 2004.

Especially to companies that release proprietary code as OSS, they face the risk of losing competitive advantage of such technology (Gabriel \& Goldman, 2002; Henkel, 2004). Competitors might use the software, or obtain insights into the developing firm's business processes (Henkel, 2004).

Especially for companies that sponsor the existing OSS and are making money selling complements to it, they have to be concerned about weather the complement is being provided cheaper or in a better quality by their competitors. If this occurs, they will lose sales opportunities (Henkel, 2004).

\section{Motivations of Companies participating in OSS Development}

A few researches of open source software have focused mainly on the motivations of open source programmers and the organization of open source projects (Kogut \& Metiu, 2001; Lerner \& Tirole, 2002a; Benkler, 2002). Feller 
and Fitzgerald (2002) have provided a comprehensive taxonomy of the motivations to take part in the open source development. They took into account these three broad motivational areas (economic, socio-political and technological). Then they further subdivided each of these motivational areas into a micro and macro level, where individual developers are the micro-level and the organization/community is the macro-level. Based on their research, Table 6 summarizes the motivations of the firms to involve in OSS development (Bonaccorsi \&Rossi, 2003). 


\section{Table 6: Taxonomy of Motivations for Firms to Participate in}

\section{OSS Development}

\begin{tabular}{|c|c|c|}
\hline $\begin{array}{l}\text { Motivation } \\
\text { Area }\end{array}$ & Macro Level & References \\
\hline \multirow{5}{*}{ Economic } & $\begin{array}{l}\text { Being independent of the price and licence policies of } \\
\text { the large software companies }\end{array}$ & Lerner \& Tirole, 2002b \\
\hline & $\begin{array}{l}\text { Addressing the new model of software as a } \\
\text { consumer-driven service (making money on } \\
\text { complementary services) }\end{array}$ & $\begin{array}{l}\text { Feller \& Fitzgerald, 2002; } \\
\text { Wichemann, 2002a }\end{array}$ \\
\hline & $\begin{array}{l}\text { Obtaining indirect revenues by selling related } \\
\text { products }\end{array}$ & $\begin{array}{l}\text { Lerner \& Tirole, 2002a; } \\
\text { Wichemann, 2002a; Feller \& } \\
\text { Fitzgerald, } 2002\end{array}$ \\
\hline & $\begin{array}{l}\text { Affording innovation (by exploiting the R\&D activity of } \\
\text { the Open Source community) }\end{array}$ & $\begin{array}{l}\text { Hawkins, 2002; von Krogh et al., } \\
2002\end{array}$ \\
\hline & Hiring good IT specialists & Fink, 2003; Wichemann, 2002b \\
\hline \multirow{3}{*}{ Social } & $\begin{array}{l}\text { Conforming to the values of the Open Source } \\
\text { community (in order not to betray the trust of the } \\
\text { Open Source developers) }\end{array}$ & $\begin{array}{l}\text { Kuster et al., 2002; Lerner \& } \\
\text { Tirole, 2002b }\end{array}$ \\
\hline & $\begin{array}{l}\text { Sharing code and knowledge with the community } \\
\text { (reciprocating in order to sustain cooperation) }\end{array}$ & $\begin{array}{l}\text { Kuster et al., 2002; Lerner \& } \\
\text { Tirole, 2002b; Franck \& } \\
\text { Jungwirth, } 2003\end{array}$ \\
\hline & $\begin{array}{l}\text { Thinking that software should not to be a proprietary } \\
\text { good (in order to reduce market power of the large } \\
\text { software companies) }\end{array}$ & Feller \& Fitzgerald, 2002 \\
\hline \multirow{5}{*}{ Technological } & $\begin{array}{l}\text { Exploiting feedback and contributions from developers } \\
\text { of the Open Source community for cutting } \\
\text { development costs and improve the software }\end{array}$ & $\begin{array}{l}\text { Hawkins, 2002; Lerner \& Tirole, } \\
\text { 2002b; Hecker, } 1999\end{array}$ \\
\hline & $\begin{array}{l}\text { Exploiting feedback and contributions from the user } \\
\text { community for testing and improving software }\end{array}$ & $\begin{array}{l}\text { Aoki et al., 2001; von Hippel, } \\
\text { 2002; Fink, } 2003\end{array}$ \\
\hline & Cutting hardware costs & Feller \& Fitzgerald, 2002 \\
\hline & Promoting standardizations & Fink, 2003; Wichemann, 2002a \\
\hline & Technological Addressing security issues & Fink, 2003 \\
\hline
\end{tabular}

Source: Bonaccorsi, A. \& Rossi, C. 2003. Comparing motivations of individual programmers and companies to take part in the open source movement. From 
community to business. Working Paper. Available at:

http://opensource.mit.edu/papers/bnaccorsirossimotivationlong.pdf

\subsection{Lessons Learned from the Literature Review}

Four important lessons were learned from the literature review.

Research on the factors that motivate large companies to invest in OSS is lacking

Most researches on adoption of open source focus on OSS adoption in small and medium firms (Dedrick \& West, 2004; Torchiano \& Morisio, 2004; Dahlander, 2004). A few researchers have studied the behavior and relationship between small and medium size companies and OSS (Nakakoji et al., 2002; Dahlander, 2004; Dahlander \& Magnusson, 2005; Rossi \& Bonaccorsi, 2005).

\section{Reasons for making OSS investments}

Large companies make OSS investments based on their perception of the benefits and risks from adopting OSS internally and contributing to OSS development externally. Detailed reasons for large companies investing in OSS are not known. 


\section{Concept of aggressiveness can be generalized to other contexts}

The conceptualization of competitive aggressiveness can be generalized to other domains, such as investments. To generalize, what is needed a sequence of events that can be measure in terms of their volume and diversity.

\section{Three types of OSS investments}

There are three types of OSS investments: release of proprietary code to an OSS project, fund or assign one or more development teams to an OSS project, and purchase or invest in an OSS company. 


\section{Research Method}

This chapter is organized into three sections. Section 3.1 identifies the unit of analysis, section 3.2 discusses the study period, and section 3.3 describes the research method.

\subsection{Unit of Analysis}

The unit of analysis is the OSS investment made by a large computer or telecommunication company. An OSS investment refers to: A. Release of proprietary code to an OSS project, B. Funding or assigning one or more development teams to an existing OSS project, and C. Purchasing or investing in an OSS company.

\subsection{Study Period}

The study period is from January 1996 to November 2005. The start of the study period corresponds to the year in which the sample companies made the first investment in OSS. The end of the study period corresponds to the year in which data collection ended. 


\subsection{Research Method}

The research method is comprised of the following eight steps:

1. Define types of OSS investments.

2. Define categories of OSS investment aggressiveness.

3. Select sample.

4. For each company in the sample, collect publicly available data of its OSS investments.

5. For each company, illustrate its OSS investment profile.

6. Categorize sample companies based on their OSS investment aggressiveness.

7. Identify the factors that drive large companies to invest in OSS.

8. Develop propositions and link them to the literature.

\section{Define Types of OSS Investment}

An OSS investment was thought of as being a competitive action event that entailed the investment in open source software. Ferrier (2001) defines a competitive action event as an externally directed, specific, and observable competitive move initiated by the company to enhance its competitive position. 
OSS investments need to be categorized. This research categorizes OSS investments into the three categories identified in the literature review (Henkel, 2004; Rossi \& Bonaccorsi, 2005):
A. Release proprietary code as an OSS project.
B. Fund or assign a development team to an existing OSS project.
C. Purchase or invest in an OSS company.

If a company first developed code as proprietary software, and then released it as OSS, the investment event is identified as a type A OSS investment.

If a company funds, sponsors or assigns a team to an existing OSS project the investment event is identified as a type B OSS investment.

If a company purchased, acquired, or invested in an OSS company, the investment event is identified as a type C OSS investment.

\section{Define Categories of OSS Investment Aggressiveness}

The companies in the sample were categorized on the basis of their OSS investment aggressiveness. Diversity and volume were used to define the various categories as follows. :

- Category 1. A company is included in the category of highest level of OSS investment aggressiveness if its Diversity $=3$ and its Volume $\geq 15$. In other 
words, a company is in Category 1 if it made all three types of OSS investments and its volume of investment events was $\geq 15$.

- Category 2. A company is included in Category 2 if its Diversity $=3$ and its Volume $<15$. In other words, a company is in Category 2 if it made all three types of OSS investments and its volume of investments was $<15$.

- Category 3. A company is included in Category 3 if its Diversity $=2$, i.e., the company made two types of OSS investments.

- Category 4. A company is included in Category 4 if Diversity $=1$, i.e., the company made one type of OSS investment.

- Category 5. A company is in the category of lowest OSS investment aggressiveness if its Diversity $=0$, i.e., the company did not make any OSS investment.

In terms of highest to lowest OSS investment aggressiveness the following held: Category 1 companies $>$ Category 2 companies $>$ Category 3 companies $>$ Category 4 companies $>$ Category 5 companies.

\section{Select Sample}

An industry expert was asked to select the companies to be included in the sample. The expert was a Chief Technology Officer of one of the largest suppliers of communication equipment in the world. He was asked to select a sample of 12 companies that represented the computer and telecommunication sectors included in the NASDAQ in a way that provides maximum variance in 
terms of software and hardware companies. NASDAQ is an acronym that stands for National Association of Securities Dealers Automated Quotations. The NASDAQ is an electronic exchange in the United States.

The NASDAQ was selected because it is the largest electronic screen-based market in the United States, both in terms of listed companies and traded shared value (NASDAQ Investor Relations, 2006).

\section{Collect Data}

For each company in the sample, data on OSS investment events was collected using the following steps:

1. Found the company's website and entered "open source" as a key phrase into the search utility provided on the website.

2. Organized the entries that resulted from the search. The entries may come from news releases, financial reports, technical articles, corporation information or other type of announcements maintained in the company's website.

3. Eliminated entries that described the same event.

4. Identified descriptions of OSS investment events.

5. From the description of each OSS investment identified, the following data was collected: 
- Name of the OSS projects to which the code was released, name of the OSS projects to which resources were allocated, and name of OSS company purchased/invested.

- Month and year when the investment was made.

- Reasons why the company invested in open source.

- Category of OSS investment.

6. Entered data into a Microsoft Excel research database.

\section{For Each Company, Illustrate its OSS Investment Profile}

OSS investments by each sample company were illustrated using the following steps:

1. Used Microsoft Excel to produce the illustration of the OSS investments of each company.

2. Counted the number of OSS investments for each OSS investment type by year.

3. Drew a timeline with numbers of the volume and diversity for each company.

4. Separated companies with higher OSS investment aggressiveness from the others.

\section{Categorize Sample Companies Based on their OSS Investment}

\section{Aggressiveness}

Sample companies were classified into different groups based on their OSS investment aggressiveness using the following steps: 
1. For each company, each OSS investment made by the company was categorized into one of three types.

2. Diversity and volume were calculated. Diversity was calculated as the number of different categories of OSS investments the company made over the study period. Thus, minimum diversity was 0 and the maximum diversity was 3 . Volume was calculated as the sum of the investment events identified in the web search. The minimum was 0 and the maximum can be an integer number.

3. Companies were classified into categories of OSS investment aggressiveness based on their diversity and volume.

\section{Identify Factors}

The following steps were used to identify the factors that drive companies to make investments in OSS:

1. For each OSS investment event identified, the reasons made public by the company for making the investment were examined. Key words were picked up or induced from the description to represent the factors that drove the OSS investment.

2. Factors identified were entered into another Excel database.

3. Factors were coded based on OSS investment types (e.g. A1, B2, or C3).

4. New factors found in new data would be added to the factors list.

5. Existing terms and codes would be used if factors from the new data could be found or found similar in the existing database. The expressions of the factors were refined if the researcher could come up with better descriptions. 
6. After all the OSS investment events were examined; the factors in the database were re-examined. If some factors were similar, they would be clustered into a group and just one term and one code would be used.

7. The factors and codes lists were expanded and refined throughout the research by continuously adding, eliminating, clustering, refining, and sorting them.

8. The numbers of codes and factors were calculated.

9. Important factors deemed to account for most of the behavior in the observed data were identified for further discussion and proposition development.

\section{Develop Propositions and Link Them to Literature}

The following steps were used to develop propositions:

1. When the data analysis of each company in the sample was completed, the factors identified and the illustrated OSS aggressiveness were reviewed and periodically at other times throughout the research. After each review, more refinements of the factor codes were done, and the relationship between factors and OSS aggressiveness was better understood.

2. The propositions of the possible causal relationship between the important factors and OSS aggressiveness were noted along with alternative explanations. 3. The related literature was reviewed again. Based on the literature, the expressions of factors were again revised and refined. The rational of the relationship between the factors and OSS aggressiveness was also well 
understood and the propositions were consolidated. Each relationship was articulated as a proposition.

Finally, a model was developed to explain the reasons why some companies were more aggressive at making OSS investments than others. The explanatory factors identified were assumed to affect volume and diversity of OSS investments. 


\section{Research Results}

This chapter is organized into three sections. The first section describes the sample. The second section provides the OSS aggressiveness of the companies in the sample. The third section identifies the factors identified as affecting OSS investment aggressiveness.

\subsection{Sample}

\section{Companies Included in the Sample}

Table 7 identifies the 12 computer and telecommunication companies in the sample and their sectors categories. All 12 companies are listed in the NASDAQ. Six companies are also listed in the New York Stock Exchange (NYSE): HP, Nokia, Motorola, Avaya, Lucent and Nortel.

Four of the 12 companies in the sample are in the NASDAQ computer sector and 8 in the telecommunications sector.

\section{Sample of OSS Investments}

Table 8 shows that 207 events anchored around investments in OSS were identified by examining the information obtained from the websites of the 
companies in the sample. Of the 207, 166 included information regarding the factors that drove the companies to make the investments.

\section{Table 7: 12 Companies in the Sample}

\begin{tabular}{|l|l|l|}
\hline \multicolumn{2}{|c|}{ NASDAQ Sector Category } & \multicolumn{1}{|c|}{ Selected Companies } \\
\hline \multirow{4}{*}{ Computer } & Diversified computer systems & HP $^{\star}$, Sun \\
\cline { 2 - 3 } & Application software & Novell \\
\cline { 2 - 3 } & Internet software \& services & Symantec/VERITAS \\
\hline \multirow{3}{*}{ Telecom } & Communication equipment & Ericsson, Nokia ${ }^{\star}$, Motorola $^{*}$ \\
\cline { 2 - 3 } & Networking \& communication devices & Juniper, Cisco \\
\cline { 2 - 3 } & Processing systems products & Avaya ${ }^{*}$, Lucent $^{\star}$, Nortel $^{\star}$ \\
\hline
\end{tabular}

Note: All companies are listed in NASDAQ. Companies with an asterisks "*" are also listed in the NYSE.

\section{Table 8: Number of Investments in the Sample}

\begin{tabular}{|l|c|}
\hline $\begin{array}{l}\text { Number of investments with information on year of OSS } \\
\text { investment and OSS investment type }\end{array}$ & 207 \\
\hline $\begin{array}{l}\text { Number of investments with information on the factors that drive } \\
\text { the companies to make the OSS investment }\end{array}$ & 166 \\
\hline
\end{tabular}

\subsection{Volume and Diversity of Investments in OSS}

For all 12 companies in the sample, Table 9 provides the volume and diversity of their investments in OSS. Table 9 shows that 10 of the 12 companies in the 
sample made OSS investments from 1996 to 2005. Two companies, Avaya and Symantec, did not make OSS investments from 1996 to 2005.

Table 9: Volume and Diversity of OSS Investments Made by Companies in the Sample

\begin{tabular}{|c|c|c|c|c|c|}
\hline Company & $\begin{array}{l}\text { Release } \\
\text { code }\end{array}$ & $\begin{array}{l}\text { Fund project } \\
\text { or assign } \\
\text { developers to } \\
\text { existing oss } \\
\text { project }\end{array}$ & $\begin{array}{l}\text { Purchase } \\
\text { or invest in } \\
\text { oss } \\
\text { company }\end{array}$ & Volume & Diversity \\
\hline Avaya & & & & 0 & 0 \\
\hline Cisco & 2 & 1 & 1 & 4 & 3 \\
\hline Ericsson & & 1 & & 1 & 1 \\
\hline $\mathrm{HP}$ & 31 & 26 & 1 & 58 & 3 \\
\hline Juniper & 1 & & & 1 & 1 \\
\hline Lucent & 4 & & 1 & 5 & 2 \\
\hline Motorola & 2 & & & 2 & 1 \\
\hline Nokia & 10 & 14 & 2 & 26 & 3 \\
\hline Nortel & 3 & & & 3 & 1 \\
\hline Novell & 7 & 11 & 3 & 21 & 3 \\
\hline Sun & 48 & 37 & 1 & 86 & 3 \\
\hline Symantec & & & & 0 & 0 \\
\hline $\begin{array}{l}\text { \# of investment } \\
\text { events }\end{array}$ & 108 & 90 & 9 & 207 & \\
\hline $\begin{array}{l}\text { \# of companies } \\
\text { investing in OSS }\end{array}$ & $\begin{array}{l}8 \text { of } 12 \\
(66 \%)\end{array}$ & $\begin{array}{l}7 \text { of } 12 \\
(58 \%)\end{array}$ & $\begin{array}{l}6 \text { of } 12 \\
(50 \%)\end{array}$ & & \\
\hline
\end{tabular}


Appendices 1 to 8 provide details of the investments in open source software made by the companies in the sample.

Table 9 shows that the number of investment events of types A and B (108 and 90 respectively) was much greater than the number of investment events of type C (9).

Table 9 shows that the volume of four companies, HP, Nokia, Novell, and Sun was 191 investment events (i.e., $58+26+21+86$ ). The volume of this four companies accounted for $92.3 \%$ of the total volume of investment events (i.e., 191/207).

Table 10 shows the 12 companies in the sample classified into five categories based on their OSS investment aggressiveness. 


\section{Table 10: Companies Categorized in Terms of their OSS}

\section{Investment Aggressiveness}

\begin{tabular}{|l|c|c|}
\hline OSS Aggressiveness & Computer & Telecommunications \\
\hline $\begin{array}{l}\text { Category 1: } \\
\text { Diversity }=3 \text {, Volume } \geq 15\end{array}$ & HP, Novell, Sun & Nokia \\
\hline $\begin{array}{l}\text { Category 2 } \\
\text { Diversity = 3, Volume }<15\end{array}$ & & Cisco \\
\hline $\begin{array}{l}\text { Category 3 } \\
\text { Diversity = }\end{array}$ & & Lucent \\
\hline $\begin{array}{l}\text { Category 4 } \\
\text { Diversity = 1 }\end{array}$ & & Ericsson, Juniper, \\
\hline $\begin{array}{l}\text { Category 5 } \\
\text { Diversity }=0\end{array}$ & Symantec & Avaya \\
\hline
\end{tabular}

Figure 4 illustrates the volume and diversity of the four companies in Category 1 , the category with the highest OSS investment aggressiveness (Diversity $=3$ and Volume $\geq 15$ ). The four companies that were most aggressive in terms of their OSS investments were: HP, Nokia, Novell, and Sun.

For each company, Figure 4 provides the number of investment events per OSS investment category undertaken by the company from 1996 to 2005. Two examples clarify how to read the information provided in Figure 4. First, Figure 4 shows that in 1996 HP made 2 type B OSS investments. This means that the researcher found information on two events in which HP funded or assigned a development team to an existing OSS project in 1996. 
The second example focuses on Sun. Figure 4 shows that in 2004 Sun made 13 type A and 4 type B OSS investments. This means that the researcher found information on 13 events in which Sun released proprietary code to an OSS project and 4 events in which Sun funded or assigned a development team to an existing OSS project.

\section{Figure 4: Volume and Diversity of Four Companies in Category 1}

\begin{tabular}{|c|c|c|c|c|c|c|c|c|c|c|}
\hline \multirow{3}{*}{ HP } & & & & & & & & & & \multirow{2}{*}{$\frac{A-3}{B-1}$} \\
\hline & & & & & A-2 & $A-15$ & $A-7$ & & & \\
\hline & B-2 & & & B-5 & B-2 & B-9 & B-4 & B-3 & $A-4$ & $\mathrm{C}-1$ \\
\hline \multirow{5}{*}{ Nokia } & 1996 & 1997 & 1998 & 1999 & 2000 & 2001 & 2002 & 2003 & 2004 & 2005 \\
\hline & & & & & & A-2 & & & & \\
\hline & & & & & & B-2 & & & $\mathrm{A}-2$ & $A-7$ \\
\hline & & & & & B-1 & $\mathrm{C}-2$ & & B-5 & B-1 & B-4 \\
\hline & 1996 & 1997 & 1998 & 1999 & 2000 & 2001 & 2002 & 2003 & 2004 & 2005 \\
\hline \multirow{4}{*}{ Novell } & & & & & & & & $A-1$ & $A-3$ & $A-3$ \\
\hline & & & & & & & & B-4 & B-1 & B-1 \\
\hline & & & & & & & B-5 & C-1 & C-1 & C-1 \\
\hline & 1996 & 1997 & 1998 & 1999 & 2000 & 2001 & 2002 & 2003 & 2004 & 2005 \\
\hline \multirow{4}{*}{ Sun } & & & & & & & & & & A-7 \\
\hline & & & & $A-1$ & $A-2$ & $A-10$ & A-1 & A-13 & $A-13$ & B-9 \\
\hline & & & A-1 & B-1 & B-7 & B-3 & B-2 & B-11 & B-4 & $\mathrm{C}-1$ \\
\hline & 1996 & 1997 & 1998 & 1999 & 2000 & 2001 & 2002 & 2003 & 2004 & 2005 \\
\hline
\end{tabular}

For the four companies in Category 1, Figure 4 shows that 167 of the 191 investments (87\%) were made during 2001-2005. 
Figure 5 illustrates the volume and diversity of the eight companies that were not in Category 1. Figure 5 shows that 13 of the 16 investments (81\%) were made during 1999-2001.

Figure 5: Volume and Diversity of Eight Companies Not in Category 1

\begin{tabular}{|c|c|c|c|c|c|c|c|c|c|}
\hline \multirow{2}{*}{ Avaya } & \multirow{3}{*}{1997} & \multirow{3}{*}{1998} & & & & \multirow{3}{*}{2002} & \multirow{3}{*}{2003} & \multirow{3}{*}{2004} & \multirow{3}{*}{$\begin{array}{c}2005 \\
\text { B-1 }\end{array}$} \\
\hline & & & 1999 & 2000 & 2001 & & & & \\
\hline \multirow[t]{2}{*}{ Cisco } & & & $A-1$ & C-1 & $A-1$ & & & & \\
\hline & 1997 & 1998 & 1999 & 2000 & 2001 & 2002 & 2003 & 2004 & 2005 \\
\hline \multirow[t]{2}{*}{ Ericsson } & & & & B-1 & & & & & \\
\hline & 1997 & 1998 & 1999 & 2000 & 2001 & 2002 & 2003 & 2004 & 2005 \\
\hline \multirow[t]{2}{*}{ Juniper } & & & & & & & & & A-1 \\
\hline & 1997 & 1998 & 1999 & 2000 & 2001 & 2002 & 2003 & 2004 & 2005 \\
\hline \multirow[t]{3}{*}{ Lucent } & & & & $\mathrm{C}-1$ & & & & & \\
\hline & $A-1$ & & $A-1$ & A-2 & & & & & \\
\hline & 1997 & 1998 & 1999 & 2000 & 2001 & 2002 & 2003 & 2004 & 2005 \\
\hline \multirow[t]{2}{*}{ Motorola } & & & & $A-1$ & $A-1$ & & & & \\
\hline & 1997 & 1998 & 1999 & 2000 & 2001 & 2002 & 2003 & 2004 & 2005 \\
\hline \multirow[t]{2}{*}{ Nortel } & & & $A-1$ & $\mathrm{~A}-2$ & & & & & \\
\hline & 1997 & 1998 & 1999 & 2000 & 2001 & 2002 & 2003 & 2004 & 2005 \\
\hline \multirow[t]{2}{*}{ Symantec } & & & & & & & & & \\
\hline & 1997 & 1998 & 1999 & 2000 & 2001 & 2002 & 2003 & 2004 & 2005 \\
\hline
\end{tabular}




\subsection{Factors that Affect OSS Investment Aggressiveness}

Table 11 provides the factors that drive investments in OSS that were identified from the data collected as well as the number of companies and investment events where the factors were identified. 


\section{Table 11: Count of the Factors Companies Stated Drive their}

\section{Investments in OSS}

\begin{tabular}{|c|c|c|c|}
\hline & Factor & $\begin{array}{l}\text { Number of } \\
\text { companies where } \\
\text { the factor was } \\
\text { identified and \% this } \\
\text { number represents } \\
\text { of the } 12 \text { companies } \\
\text { in sample }\end{array}$ & $\begin{array}{l}\text { Number of investment } \\
\text { events where the } \\
\text { factor was identified } \\
\text { and \% this number } \\
\text { represents of the } \\
166 \text { investment } \\
\text { events identified }\end{array}$ \\
\hline 1 & $\begin{array}{c}\text { OSS performs better than } \\
\text { alternatives along dimensions that } \\
\text { users care about }\end{array}$ & $9(75 \%)$ & $106(63.9 \%)$ \\
\hline 2 & $\begin{array}{l}\text { Use OSS for internal product } \\
\text { development }\end{array}$ & $10(83 \%)$ & $79(47.6 \%)$ \\
\hline 3 & Savings from using OSS & $6(50 \%)$ & $47(28.3 \%)$ \\
\hline 4 & Support for open standards & $10(83 \%)$ & $44(26.5 \%)$ \\
\hline 5 & $\begin{array}{l}\text { Revenue from new products and } \\
\text { new markets }\end{array}$ & $4(33 \%)$ & $23(13.9 \%)$ \\
\hline 6 & Use as module by others & $3(25 \%)$ & $10(8.3 \%)$ \\
\hline 7 & Provide users with more control & $4(33 \%)$ & $6(3.6 \%)$ \\
\hline 8 & Reduce knowledge barrier & $4(33 \%)$ & $4(2.4 \%)$ \\
\hline 9 & $\begin{array}{l}\text { Release code to provide benefits to } \\
\text { all adopters }\end{array}$ & $2(17 \%)$ & $4(2.4 \%)$ \\
\hline 10 & $\begin{array}{l}\text { Release code to help others reduce } \\
\text { costs }\end{array}$ & $3(25 \%)$ & $3(1.8 \%)$ \\
\hline 11 & $\begin{array}{l}\text { Speed resolution of technical } \\
\text { problems }\end{array}$ & $2(17 \%)$ & $2(1.2 \%)$ \\
\hline 12 & Committed to OSS strategy & $2(17 \%)$ & $2(1.2 \%)$ \\
\hline 13 & $\begin{array}{l}\text { Establish good business } \\
\text { relationships }\end{array}$ & $1(8 \%)$ & $1(0.6 \%)$ \\
\hline 14 & Encourage communications & $1(8 \%)$ & $1(0.6 \%)$ \\
\hline
\end{tabular}


Table 11 shows that the researcher identified 14 factors that drive the investment in OSS. The five factors with the highest frequency count were: i. OSS performs better than alternatives along dimensions that users care about, ii. Use OSS for internal product development, iii. Savings from using OSS, iv. Support for open standards, and v. Increase revenue from new products and new markets. For each factor, the number of companies for which the factor was identified as a percentage of 12 (i.e., sample size) and the number of investment events for which the factor was identified as a percentage of 166 (i.e., total number of investment events identified) were greater than $33 \%$ and $10 \%$ respectively. These five factors were identified as being the most important factors that drive large companies to invest in OSS.

For each of the 14 factors identified as driving OSS investments, Table 12 provides a description and the key words and phrases that represented them. 


\section{Table 12: Factors that Drive Investments in OSS}

\begin{tabular}{|c|c|c|c|}
\hline & Factor & Description of factor & Key words and phrases \\
\hline \multirow{3}{*}{1} & \multirow{3}{*}{$\begin{array}{l}\text { OSS performs } \\
\text { better than } \\
\text { alternatives along } \\
\text { dimensions that } \\
\text { users care about }\end{array}$} & Technology performance & $\begin{array}{l}\text { Innovative features, more powerful } \\
\text { and efficient, superior compliance, } \\
\text { differentiation }\end{array}$ \\
\hline & & Interoperability & $\begin{array}{l}\text { Extendible, flexible, interoperable, } \\
\text { compatible, scalable, works across } \\
\text { multiple platforms, one fits-all }\end{array}$ \\
\hline & & Simplicity & $\begin{array}{l}\text { Ease of use, small-size, light- } \\
\text { weight, clean, convenient }\end{array}$ \\
\hline 2 & $\begin{array}{l}\text { Use OSS for } \\
\text { internal product } \\
\text { development }\end{array}$ & $\begin{array}{l}\text { Use OSS projects for } \\
\text { company's own products, } \\
\text { either open or closed }\end{array}$ & $\begin{array}{l}\text { Be used or embedded in company's } \\
\text { own product, be complementary } \\
\text { technology of }\end{array}$ \\
\hline 3 & $\begin{array}{l}\text { Savings from using } \\
\text { OSS }\end{array}$ & $\begin{array}{l}\text { Use of community to save } \\
\text { money required to improve } \\
\text { quality, safety, features and } \\
\text { advance technology }\end{array}$ & $\begin{array}{l}\text { Use of community to improve } \\
\text { technology and technology related } \\
\text { features, increase quality and } \\
\text { security }\end{array}$ \\
\hline 4 & $\begin{array}{l}\text { Support for open } \\
\text { standards }\end{array}$ & $\begin{array}{l}\text { Top management team's } \\
\text { support for Linux and other } \\
\text { open standard development }\end{array}$ & $\begin{array}{l}\text { Linux development, support open } \\
\text { standards }\end{array}$ \\
\hline 5 & $\begin{array}{l}\text { Revenue from new } \\
\text { products and new } \\
\text { markets }\end{array}$ & $\begin{array}{l}\text { Attract new users and address } \\
\text { new markets }\end{array}$ & $\begin{array}{l}\text { Attract a greater number of users, } \\
\text { disseminate the technology, } \\
\text { increase market share }\end{array}$ \\
\hline 6 & $\begin{array}{l}\text { Use as module by } \\
\text { others }\end{array}$ & $\begin{array}{l}\text { Be used as a module by } \\
\text { others }\end{array}$ & $\begin{array}{l}\text { Be used as a module, be used as a } \\
\text { building block }\end{array}$ \\
\hline
\end{tabular}




\begin{tabular}{|c|c|c|c|}
\hline & Factor & Description of factor & Key words and phrases \\
\hline 7 & $\begin{array}{l}\text { Provide users with } \\
\text { more control }\end{array}$ & $\begin{array}{l}\text { Provide users with more } \\
\text { control }\end{array}$ & More user control, close to user \\
\hline 8 & $\begin{array}{l}\text { Reduce knowledge } \\
\text { barrier }\end{array}$ & $\begin{array}{l}\text { Reduce the knowledge barrier } \\
\text { for standards or other } \\
\text { technologies }\end{array}$ & $\begin{array}{l}\text { Remove the barriers for different } \\
\text { platforms, reduce the knowledge } \\
\text { barrier for open standard }\end{array}$ \\
\hline 9 & $\begin{array}{l}\text { Release code to } \\
\text { provide benefits to } \\
\text { all adopters }\end{array}$ & $\begin{array}{l}\text { Release code to provide } \\
\text { benefits to all adopters }\end{array}$ & Provide benefits to all adopters \\
\hline 10 & $\begin{array}{l}\text { Release code to } \\
\text { help others reduce } \\
\text { costs }\end{array}$ & $\begin{array}{l}\text { Release code to help others } \\
\text { reduce costs in product or } \\
\text { technology development }\end{array}$ & Reduce costs \\
\hline 11 & $\begin{array}{l}\text { Speed resolution of } \\
\text { technical problems }\end{array}$ & $\begin{array}{l}\text { Speed resolution of technical } \\
\text { problems for users }\end{array}$ & $\begin{array}{l}\text { Speed resolution of technical } \\
\text { problems }\end{array}$ \\
\hline 12 & $\begin{array}{l}\text { Committed to OSS } \\
\text { strategy }\end{array}$ & $\begin{array}{l}\text { Contribute to OSS } \\
\text { development because of their } \\
\text { commitment to OSS strategy }\end{array}$ & Commitment to OSS strategy \\
\hline 13 & $\begin{array}{l}\text { Establish and } \\
\text { strengthen business } \\
\text { relationship }\end{array}$ & $\begin{array}{l}\text { Release code to establish } \\
\text { good business relationships } \\
\text { with users }\end{array}$ & $\begin{array}{l}\text { Establish good business } \\
\text { relationships }\end{array}$ \\
\hline 14 & $\begin{array}{l}\text { Encourage } \\
\text { communications }\end{array}$ & $\begin{array}{l}\text { Encourage communication } \\
\text { between developer and } \\
\text { community }\end{array}$ & $\begin{array}{l}\text { Encourage communication between } \\
\text { developer and community }\end{array}$ \\
\hline
\end{tabular}

Appendices 9 to 11 provide the frequency count of factors of OSS investment type $A, B$, and $C$ in terms of sample companies. 


\section{Discussion of Results}

This chapter is organized into four sections. Section 5.1 discusses the results on OSS investment aggressiveness. Section 5.2 identifies the factors identified to drive the volume and diversity of a company's investments in OSS. Section 5.3 relates the factors identified with the literature stream on development decisions. Finally, section 5.4 provides propositions anchored around a model for the factors that affect the OSS investment aggressiveness of large companies.

\subsection{OSS Investment Aggressiveness}

The sample was comprised of the 12 companies shown in Table 7. Four of these companies were in the NASDAQ computer sector and 8 in the NASDAQ telecommunications sector.

Table 8 shows that a total of 207 events were identified whereby a company in the sample invested in OSS. Table 9 shows that of these 207 OSS investment events, $108(52 \%)$ entailed the release of code to open source projects, $90(44 \%)$ entailed funding or assigning developers to open source projects, and $9(4 \%)$ entailed purchasing or investing in an open source software company. 
Table 10 organizes the 12 companies in the sample into five categories based on their diversity and volume of OSS investments. Category 1 included the large computer and telecommunication companies that were the most aggressive in terms of their investments in OSS. These four companies represented 191 of the 207 investments in OSS that were identified or $92 \%$. Three of the four companies in Category 1 were computer companies. Five of the eight telecommunications companies in the sample were in Categories 4 and 5 , the two categories that included the least OSS investment aggressive companies.

Figure 4 shows that the four companies in Category 1 made 167 of 191 investments in OSS (87\%) during 2001-2005. Figure 5 shows that the eight companies not in Category 1 made 13 of 16 investments in OSS (81\%) during 1999-2001. The results suggest that the companies in Category 1 had positive experiences with investments made in 1999-2001 and continued to make OSS investments during 2001-2005 while the companies in Categories 2, 3 and 4 may have had less positive experiences with their investments in OSS during 19992001 and did not continue to invest during 2001-2005.

\subsection{Factors that Drive OSS Investment Aggressiveness}

Table 11 shows the 14 factors identified to drive large company investments in OSS. The five factors deemed to be the most important drivers of large company investment in OSS were: 
1. OSS performs better than alternatives along dimensions that users care about

2. Use OSS for internal product development

3. Savings from using OSS

4. Support for open standards

5. Increase revenue from new products and new markets

Large companies invest in OSS when the OSS performs better than alternatives. The finding that the relative performance characteristics of OSS drives OSS investments is consistent with research findings reported by Rogers (1983, 1995, 2003), Tornatzky and Klein (1982), and Dedrick and West (2004).

Large companies invest in OSS because they use the OSS in their development projects as operating systems, development environments, tools, and applications for their own products (hardware or software) and services. Take the data for Nokia as an example. Of the 24 OSS investments made by Nokia, 11 were made to build the software environment for the Nokia 770 , pocket-size, Linux-powered Web browser. Table 13 identifies the 11 OSS investments that Nokia made to support its Nokia 770 . Of the 11 investments shown in Table 13, ten entailed sponsoring existing projects and one entailed releasing code. 
Table 13: OSS Investments Related to the Nokia 770

\begin{tabular}{|c|c|l|l|}
\hline & Investment type & \multicolumn{1}{|c|}{ Investment name } & \multicolumn{1}{|l|}{$\begin{array}{c}\text { Investing } \\
\text { time }\end{array}$} \\
\hline 1 & B & $\begin{array}{l}\text { Linux operating system } \\
\text { kernel }\end{array}$ & 2000.09 \\
\hline 2 & B & C++ and uClibc C-library & 2001.05 \\
\hline 3 & B & GPE & 2003.06 \\
\hline 4 & B & Scratchbox & 2003.08 \\
\hline 5 & A & maemo & 2005.05 \\
\hline 6 & B & GnomeVFS & 2005.05 \\
\hline 7 & B & D-BUS & 2005.05 \\
\hline 8 & B & GConf & 2005.05 \\
\hline 9 & B & GStreamer & 2005.07 \\
\hline 10 & B & BlueZ library & 2001.08 \\
\hline 11 & B & Matchbox & 2003 \\
\hline
\end{tabular}

Data for Novell provides another example of how the use of OSS for internal development drives companies to invest in OSS. Table 14 shows the seven OSS investments Novell made to support Novell Netware, a product used to provide integrated solutions for business continuance and Web services that promote end-user productivity and assure non-stop access to network resources (Novell NetWare Reviewer's Guide, 2006). All seven OSS investments were of 
type B given that they entailed funding an OSS project or allocating developers to support the OSS project.

Table 14: OSS Investments Related to Novell NetWare

\begin{tabular}{|c|c|l|l|}
\hline & Investment type & Investment name & Investing time \\
\hline 1 & B & Apache HTTP Server & 2002 \\
\hline 2 & B & MySQL & 2002 \\
\hline 3 & B & Perl & 2003 \\
\hline 4 & B & PHP & 2003 \\
\hline 5 & B & PostgreSQL & 2002 \\
\hline 6 & B & Rysnc & 2002 \\
\hline 7 & B & Tomcat & 2002 \\
\hline
\end{tabular}

Large companies invest in OSS to reduce their development costs. Company investment in OSS attracts experience developers to contribute to improve the software (McGrath, 1997). Communities of developers for which the company does not have to pay fix bugs, solve difficult problems, improve quality and add functionality to the OSS. Examples of companies that invested in OSS to reduce their development costs include Sun's release of OpenOffice, Novell's release of iFolder, HP support for Apache and Sun's support for openSSL.

Large companies invest in OSS when their top management teams support open standards adoption. For example, HP's top management team supports Linux 
adoption. From 1999 to 2005, HP made the 22 investments shown in Table 15 to support Linux adoption.

Table 15: OSS Investments for Linux in HP

\begin{tabular}{|c|c|c|c|}
\hline & $\begin{array}{c}\text { Investment } \\
\text { type }\end{array}$ & Investment name & Investing time \\
\hline 1 & $\mathrm{~B}$ & parisc-linux & 1999 \\
\hline 2 & B & HP Office Jet Linux driver & 1999 \\
\hline 3 & A & HP LaserJet Linux Drivers & 2000 \\
\hline 4 & A & HP Linux Inkjet Driver project & 2000 \\
\hline 5 & B & Handhelds & 2000 \\
\hline 6 & B & IA64-linux & 2000 \\
\hline 7 & $A$ & Cluster Infrastructure for Linux & 2001 \\
\hline 8 & A & OpenSSI Clusters for Linux & 2001 \\
\hline 9 & A & PCI Hot Plug for Linux & 2001 \\
\hline 10 & A & Shoreline Firewall & 2001 \\
\hline 11 & $\mathrm{~B}$ & Samba & 2001 \\
\hline 12 & $B$ & Debian & 2001 \\
\hline 13 & B & aboot & 2001 \\
\hline 14 & B & PPTP Client & 2001 \\
\hline 15 & A & Performance Monitoring & 2002 \\
\hline 16 & A & Storage Performance Monitor for Linux & 2002 \\
\hline 17 & B & Prospect & 2002 \\
\hline 18 & B & Hendrix - Lustre File System Development & 2003 \\
\hline 19 & B & elilo & 2003 \\
\hline 20 & A & Q-tools & 2004 \\
\hline 21 & 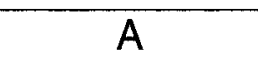 & LinuxCOE & 2005 \\
\hline 22 & $\mathrm{C}$ & RLX Technologies & 2005 \\
\hline
\end{tabular}


Large companies invest in OSS to increase revenue from sales of new products and/or in new markets. For example, Sun invested in NetBeans and Open Office expecting to increase revenues from new products and new markets. Similarly, Novell invested in Hula and OpenSUSE Linux to increase its sales.

Data on appendices 9 to 11 show that three factors, "OSS performs better than alternatives", "Use OSS for internal product development" and "Support for open standards", appear on all three tables with higher frequency count. They are the ones that most affect large companies to invest in OSS.

\subsection{Factors Identified and Product Development Decisions}

Krishnan and Ulrich (2001) identify 30 major decisions that are made when developing a product and organize them into two broad categories: i. decisions made within the context of a single product when actually developing the product and ii. decisions a firm makes when establishing an organizational context and in planning development projects. The results suggest that the factors that drive large company investments in OSS can also be organized into two broad categories: i. factors related to the specific product being developed and ii. factors related to the organizational context and planning. The first three important factors seem to be related to the specific product being developed. The first important factor "OSS performs better than alternatives along dimensions that users care about" relates to product design decisions. The second and third 
important factors, "Use OSS for internal product development" and "Savings from using OSS" relate to supply chain design decisions.

The fourth and fifth important factors seem to be related to organizational context and planning decisions. The fourth factor, "Support for open standards" and the fifth factor "Revenue from new products and new markets" relate to product strategy and planning decisions.

At a higher level of abstraction, the results support an argument that says that the decisions pertaining product design, supply chain design and product strategy and planning are the ones that most affect large companies investments in OSS.

\subsection{Model and Propositions}

Figure 6 provides a model that identifies the factors that drive large companies to invest in OSS. The unit of analysis is OSS investment event (OSS projects or OSS company), but the propositions will be provided at the company level. 
Figure 6: Factors that Drive Large Companies to Invest in OSS

FACTORS
Product design decisions
- Relative performance of OSS in
dimensions that users care about
Supply chain design decision
- Use of OSS for internal
development
- Savings from using OSS
Product strategy and planning
decisions
- Support for open standards
- Revenue from new products and
markets

The following five propositions anchored around the model shown in Figure 6 are offered:

Proposition 1: The extent to which OSS perform better than alternatives in the technical dimensions that users care about is positively related to a company's open source investment aggressiveness.

Proposition 2: The extent OSS is used in internal product development is positively related to a company's open source investment aggressiveness. 
Proposition 3: The extent to which OSS reduces development costs is positively related to a company's open source investment aggressiveness.

Proposition 4: Top management team's support for open standards is positively related to a company's open source investment aggressiveness.

Proposition 5: The extent to which revenues depend on new products and new markets is positively related to a company's open source aggressiveness. 


\section{Conclusions, Limitations, and Suggestions for Future Research}

This chapter is organized into three sections. Section 6.1 provides the conclusions of this research. Section 6.2 describes the limitations of this research. Finally section 6.3 provides suggestions for future research.

\subsection{Conclusions}

\section{Answers to research questions}

The objective of this research was to examine the investments that large computer and telecommunication companies make in OSS and the factors that affect a large company's investment in OSS. This research answers two questions:

1. Which large computer and telecommunication companies are more aggressive than others in terms of their investments in OSS?

2. What are the factors that drive a large computer or telecommunication company to invest in OSS?

The results of this research suggest that three computer companies, HP, Novell and Sun, and one telecommunications company, Nokia, were the most 
aggressive in terms of their investments in OSS. Five of the eight telecommunication companies in the sample were organized in the categories that were the least aggressive in terms of OSS investments.

The results of this research also suggest that decisions on product design, supply chain design, and product strategy and planning affect the volume and diversity of the OSS investments made by large companies.

Five propositions are offered. The volume and diversity of OSS investments made by large companies is conceptualized as being driven by the relative performance of OSS in the dimensions that users care about, use of OSS for internal product development, savings from using OSS, support for open standards, and revenue from new product-markets.

\section{Operationalizing OSS investment aggressiveness}

OSS investment aggressiveness can be operationalized using the volume and diversity of a company's OSS investments. Data is freely and publicly available. An OSS strategy can be considered as a sequence of investments in OSS projects with dimensions of volume and diversity over time. Companies intend to set up more and diverse OSS investments to produce positive returns to improve its market position. 


\subsection{Limitations}

This research has at least two limitations.

The first limitation is that this research used information collected from company websites. Company personnel was not interviewed. This means that the research can't tell why some companies use OSS but do not invest in it.

The second limitation is that the propositions are described at the company level when the unit of analysis was the OSS investment event.

\subsection{Suggestions for Future Research}

Future researchers can first develop hypotheses from the propositions identified in this research and then test them.

The second suggestion for future research is to concurrently examine $i$. the relationship between antecedent factors and volume and diversity of OSS investments and ii. the relationship between volume and diversity of OSS investments and company performance. 
The third suggestion for future research would be to examine the success of the OSS investment. During the period of the data collection, some projects had failed or were found inactive. Success of OSS investments is relevant to companies and it may have a relationship with OSS community evolution. Companies may apply OSS development to their regular product offerings by recognizing and fostering the development of communities around those products. By helping to make these communities successful the company can increase the success of its products (Gabriel \& Goldman, 2002). Researchers could collect further data to distinguish the successful and unsuccessful investments of each of the OSS projects. 


\section{References}

Aoki, A., Hayashi, K., Kishida, A., Nakakoji, K., Nishinaka, Y., Reeves, B.,

Takashima, A. \& Yamamoto, Y. 2001. A case study of the evolution of Jun: an object oriented Open Source 3D multimedia library. Proceeding of the 23rd ICSE Conference Toronto. Available at: http://www.kid.rcast.u-

tokyo.ac.jp/ kumiyo/mypapers/ICSE2001.pdf

Basili, V. \& Boehm, B. 2001. COTS-Based Systems Top 10 List. Computer, IEEE, 34(5): 91-93.

Benkler, Y. 2002. Coase's Penguin, or, Linux and the Nature of the Firm. Yale Law Journal, Forthcoming. Available at:

http://www.benkler.org/CoasesPenguin.PDF

Boehm, B. 2000. Requirements that handle IKIWISI, COTS, and rapid change. Computer, IEEE, 33(7): 99-102.

Boehm, B. \& Abts, C. 1999. COTS Integration: Plug and Pray? Computer, IEEE, 32(1): 135-138. 
Bonaccorsi, A. \& Rossi, C. 2003. Comparing motivations of individual programmers and companies to take part in the open source movement. From community to business. Working Paper. Available at:

http://opensource.mit.edu/papers/bnaccorsirossimotivationlong.pdf

Brynjolfsson, E. \& Kemerer, C. F. 1996. Network externalities in microcomputer software: An econometric analysis of the spreadsheet market. Management Science, 42(12): 1627-1647.

Dahlander, L. 2004. Appropriating returns from open innovation processes: $A$ multiple case study of small firms in open source software. Working Paper, Department of Industrial Dynamics School of Technology Management and Economics, Chalmers University of Technology.

Dahlander, L. \& Magnusson, M. G. 2005. Relationships between open source software companies and communities: Observations from Nordic firms. Research Policy, 34(4): 481-493.

Dedrick, J. \& West, J. 2004. An exploratory study into open source platform adoption. System Sciences, Proceedings of the 37th Annual Hawaii International Conference, 5-8 January. 
Egyed, A., Medvidovic, N., \& Gacek, C. 2000. Component-Based Perspective on Software Mismatch Detection. IEEE Proc.-Software, 147(6): 225-236.

Feller, J. \& Fitzgerald, B. 2002. Understanding Open Source Software Development, Addison Wesley, Boston.

Farrell, J. \& Saloner, G. 1988. Coordination through committees and markets. Rand Journal of Economics, 19(2): 235-252.

Ferrier, W. J. 2001. Navigating the competitive landscape: the drivers and consequences of competitive aggressiveness. Academy of Management Journal, 44(4): 858-877.

Ferrier, W. J., Smith, K. G., \& Grimm, G. 1999. The role of competitive action in market share erosion and industry dethronement: A study of industry leader and challengers. Academy of Management Journal, 42(4): 372-388.

Fichman, R. G. 2004. Real Options and IT Platform Adoption: Implications for Theory and Practice. Information Systems Research, 15(2):132-154.

Fink, M. 2003. The business and economics of Linux and Open Source, Prentience Hall, Upper Saddle River, NJ. 
Franck, E. \& Jungwirth, C. 2003. Reconciling rent-seekers and donators -The governance structure of open source. Journal of Management and Governance, 7(4): 401-421.

Gabriel, R. P. \& Goldman, R. 2002. Open source: beyond the fairytales. Working Paper, Sun Microsystems.

Hawkins, R. 2002. The economics of the Open Source Software for a competitive firm. MIT Working Paper. Available at:

http://www.personal.psu.edu/faculty/r/e/reh18/research/01.sce/Open Source.con ference.pdf

Hecker, F. 1999. Setting up shop: the business of Open-Source software. IEEE Software, 16 (1). 45-51.

Henkel, J. 2004. Open source software from companies - tools, complements, and collective invention. Zeitschrift für Betriebswirtschaft, Supplement 4, 1-23. Avalaible at: http://www.inno-tec.bwl.unimuenchen.de/forschung/henkel/OSS_JHenkel_2003-05.pdf

Katz, M. L. \& Shapiro, C. 1985. Network Externalities, Competition, and Compatibility. American Economic Review, 75(3): 424-440. 
Klemperer, P. 1987. The Competitiveness of Markets with Switching Costs. Rand Journal of Economics, 18(1): 138-150.

Koenig, J. 2004. Seven open source business strategies for competitive advantage. IT Manager's Journal, May 14.

Kogut, B. \& Metiu, A. 2001. Open-source software development and distributed innovation. Oxford Review of Economic Policy, 17(2): 248-264.

Krishnan, V. \& Gupta, S. 2001. Appropriateness and Impact of Platform-Based Product Development. Management Science, 47(1): 52-68.

Krishnan, V. \& Ulrich, K. 2001. Product development decisions: A review of the literature. Management Science. 47(1): 1-21.

Kuster, B., Osterloh, M. \& Rota, S. 2002. Trust and commerce in Open Sourcea contradiction? MIT Working Paper. Available at: http://www.iou.unizh.ch/orga/downloads/publikationen/osterloh rota kuster.pdf

Lawlis, P. K., Mark, K. E., Thomas, D. A. \& Courtheyn, T. 2001. A formal process for evaluating COTS software products. IEEE Computer, 34(5): 58-63. 
Lawton, G. 2002. Open source security: opportunity or oxymoron? Computer, IEEE, 35(3): 18-21.

Lerner, J. \& Tirole, J. 2002a. Some simple economics of open source. Journal of Industrial Economics, 50(2): 197-234.

Lerner J. \& Tirole J. 2002b. The Scope of Open Source Licensing. MIT Working Paper. Avalaible at: http://opensource.mit.edu/papers/lernertirole2.pdf

Lerner, J. \& Tirole, J. 2004. The economics of technology sharing: open source and beyond. Working paper. Available at: http://www.nber.org/papers/W10956.

Levin, R. C., Klevorick, A. K., Nelson, R. \& Winter, S. 1987. Appropriating the returns from industrial research and development. Brookings Papers on Economic Activity (3): 783-831.

McGrath, R. G. 1997. A Real Options Logic for Initiating Technology Positioning Investments. Academy of Management Review, 22(4): 974-996.

Morisio, M., Seaman, C. B., Parra, A. T., Basili, V. R., Kraft, S. E. \& Condon, S. E. 2000. Investigating and Improving a COTSBased Software Development Process. Proceeding on 22nd International Conference of Software Engineering, ACM Press: 32-41. 
Nakakoji, K., Yamamoto, Y., Kishida, K., \& Ye, Y. 2002. Evolution patterns of open-source software systems and communities. Proceedings of The International Workshop on Principles of Software Evolution, Orlando Florida, May: 19-20.

NASDAQ Investor Relations. 2006. Available at: http://ir.nasdaq.com/

Novell NetWare Reviewer's Guide. 2006. Available at: http://www.novell.com/collateral/4820935/4820935.pdf

Paulson, J. W., Succi, G. \& Eberlein, A. 2004. An empirical study of open-source and closed-source software products. IEEE Transactions on Software Engineering, 30(4): 246-256.

Raymond, E. 2001. The cathedral \& the Bazaar. Musings on Linux and Open Source by an Accidental Revolutionary. O'Reilly \& Associates, Sebastopol, CA.

Rogers, E. M. 2003. Diffusion of innovations, $5^{\text {th }}$ ed., New York: Free Press. Rogers, E. M. 1995. Diffusion of innovations, $4^{\text {th }}$ ed., New York: Free Press. Rogers, E. M. 1983. Diffusion of innovations, $3^{\text {rd }}$ ed., New York: Free Press. 
Rossi, C. \& Bonaccorsi, A. 2005. Why profit-oriented companies enter the OS field? Intrinsic vs. extrinsic incentives. Open Source Application Spaces: Fifth Workshop on Open Source Software Engineering (5-WOSSE), May 17, 2005, St Louis, MO, USA.

Ruffin, M. \& Ebert, C. 2004. Using open source software in product development: a primer. Software, IEEE, 21(1):82 - 86.

Torchiano, M. \& Morisio, M. 2004. Overlooked aspects of COTS-based development. Software, IEEE, 21(2): 88-93.

Tornatsky, L. G. \& Klein, K. J. 1982. Innovation Characteristics and Innovation Adoption Implementation. IEEE Transactions on Engineering Management, 29(1): 28-45.

Tornatzky, L. G. \& Fleischer, M. 1990. The processes of technological innovation, Lexington, Mass.: Lexington Books.

von Hippel, E. 2002. Open source projects as horizontal innovation networks - by and for users. SSRN Working Paper. Available at: http://www.oecd.org/dataoecd/59/59/32125887.pdf 
von Krogh, G., Lakhani, K. \& Spaeth, S. 2003. Community, joining, and specialization in open source software innovation: a case study. Research Policy, 32(7): $1217-1241$.

von Weizsäcker, C. C. 1984. The Costs of Substitution. Econometrica, 52(5): 1085-1116.

Wichmann, T. 2002a. Firms' Open Source activities: motivations and policy implications. Free/Libre and Open Source Software: Survey and Study, FLOSS Final Report. Available at: http://www.open-

source.gr/content/modules/downloads/Motivations Policy Implications Part II.p $\underline{\mathrm{df}}$

Wichmann, T. 2002b. Use of Open Source Software in Firms and Public Institutions. Evidence from Germany, Sweden and UK. Free/Libre and Open Source Software: Survey and Study, FLOSS Final Report. Available at: http://www.berlecon.de/studien/downloads/200207FLOSS Use.pdf

Yakimovich, D., Bieman, J., \& Basili, V. 1999. Software Architecture Classification for Estimating the Cost of COTS Integration. Proceeding on 21st International Conference of Software Engineering, ACM Press: 296-302. 


\section{Appendices}

\section{Appendix 1: Investments in OSS by HP}

HP is the global enterprise open source and Linux leader. HP was the first vendor to ship over one million servers and has been consistently ranked number one for Linux server units and factory revenues. HP also leads in Linux innovation - supporting Linux from desktop to datacenter, certifying best-of-breed third party solutions like JBoss and MySQL, pioneering Linux on HP Linux BladeSystem, scaling Linux up to 64P, and empowering 3D graphical workstations (Open Source \& Linux from HP, 2006).

HP lists about 57 sponsored OSS projects in its opensource.hp.com website. Among those 57 OSS projects, 31 projects were released from proprietary technology to open source (OSS investment type A) and 26 projects are the existing projects sponsored by HP (OSS investment type B). HP acquired one open source related company named RLX Technologies in 2005 , which belongs to type C OSS investment. Figure 7 illustrates how HP puts OSS investments from 1996 to 2005. 


\section{Figure 7: Investments in OSS by HP}

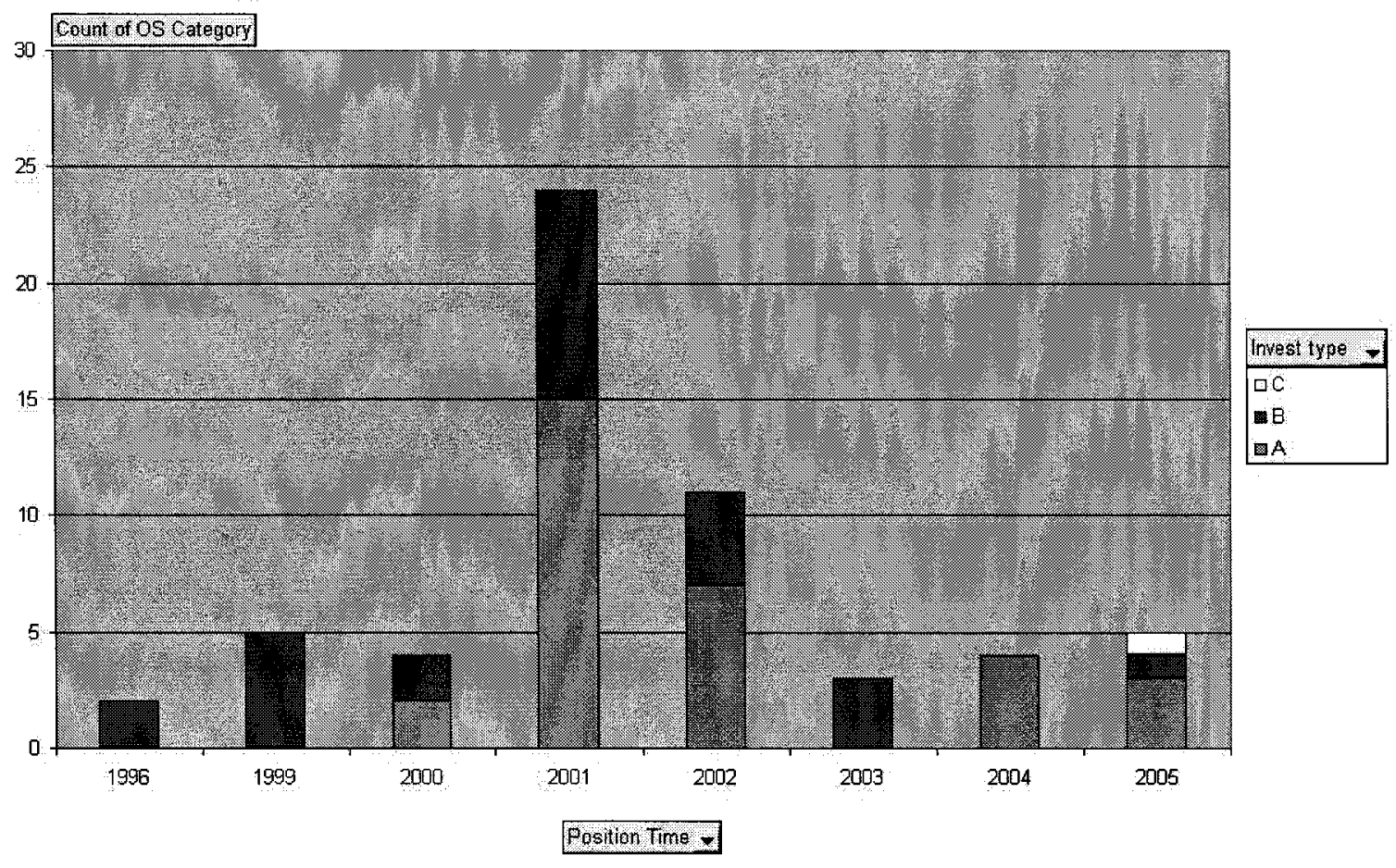




\section{Appendix 2: Investments in OSS by Novell}

Novell actively gives back to the open source community, tracks and champions standards within OASIS, the W3C, and the Java Community Process (Open Source \& Novell, 2006). In its official website, Novell has listed 18 important OSS projects. Among those 18 OSS projects, 7 projects are proprietary technology released from Novell to open source (OSS investment type A) and 11 projects are existing projects sponsoring by Novell (OSS investment type B). Novell acquired Ximian in 2003, SUSE LINUX in 2004 and Immunix in 2005 alternatively (OSS investment type C). Novell also launched Novell Forge in 2003 for OSS collaboration and Novell Forge has over 800 listed projects and 30,000 users now (Novell Forge Road Map, 2006). Figure 8 illustrates the OSS investments set up by Novell from 2002 to 2005. 


\section{Figure 8: Investments in OSS by Novell}

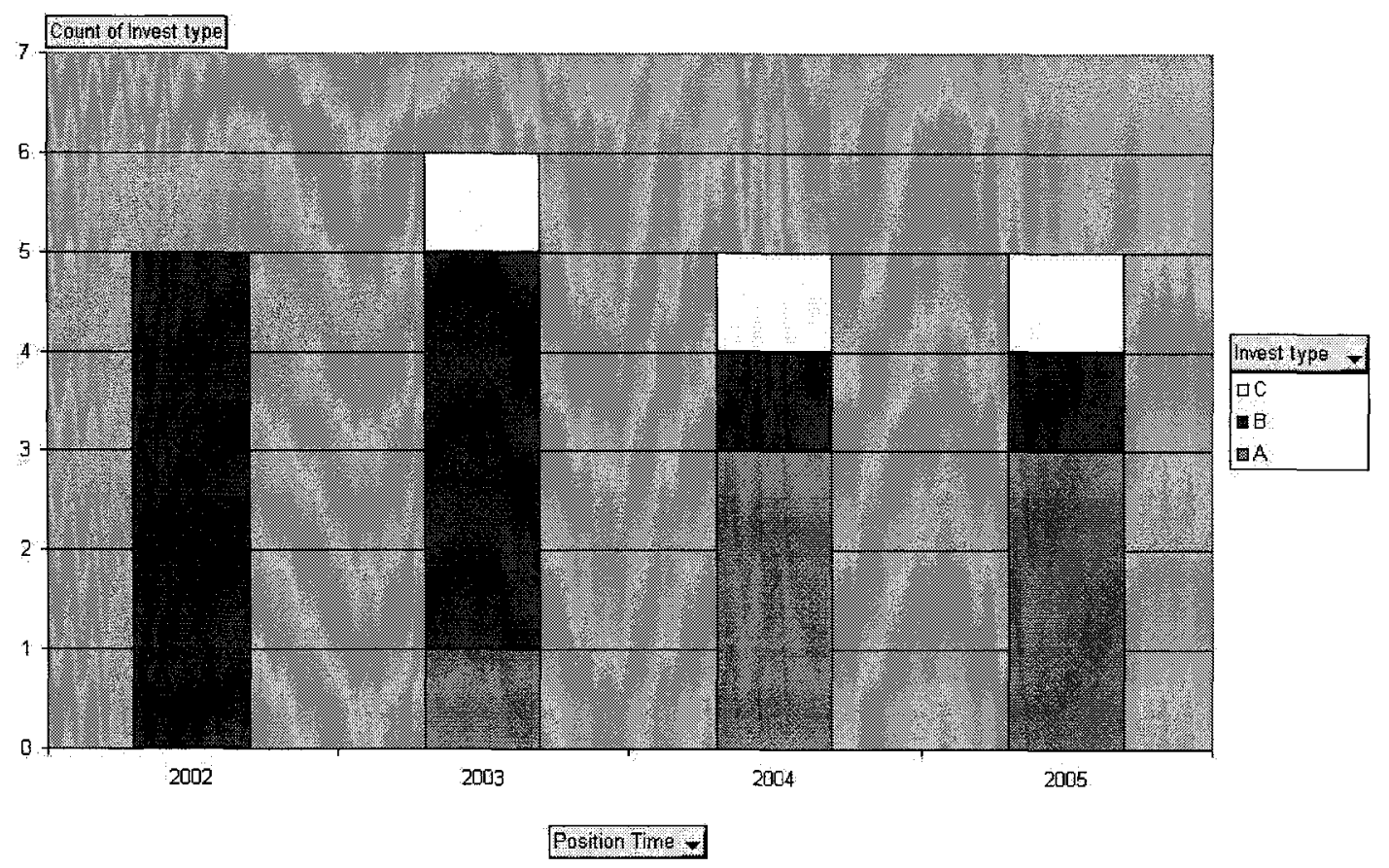




\section{Appendix 3: Investments in OSS by Sun}

Sun Microsystems produces software systems, platforms, and applications that run on both Sun and other hardware. Because of its interest and investment in software, Sun is dedicated to advancing the state and practice of the software arts and sciences. Particular importance to Sun is the concept of openness. Producing open systems has been the hallmark of Sun's business philosophy since its founding. (Why is Sun Doing Open Source? 2006)

Over 80 OSS projects were found in its official websites. Among those projects, 48 projects are released by Sun from proprietary technology to open source (OSS investment type A) and 37 projects are sponsoring as existing OSS projects (OSS investment type B). Among those projects, only 44 projects with available data can be used for analysis. Sun acquired Tarantella Inc. in 2005, which belongs to OSS investment type C. Sun launched sunsource.net in 2001, experimentalstuff.com in 2001, and java.net in 2003 for open source initiatives alternatively. Figure 9 illustrates the OSS investments made by Sun from 1998 to 2005. 
Figure 9: Investments in OSS by Sun

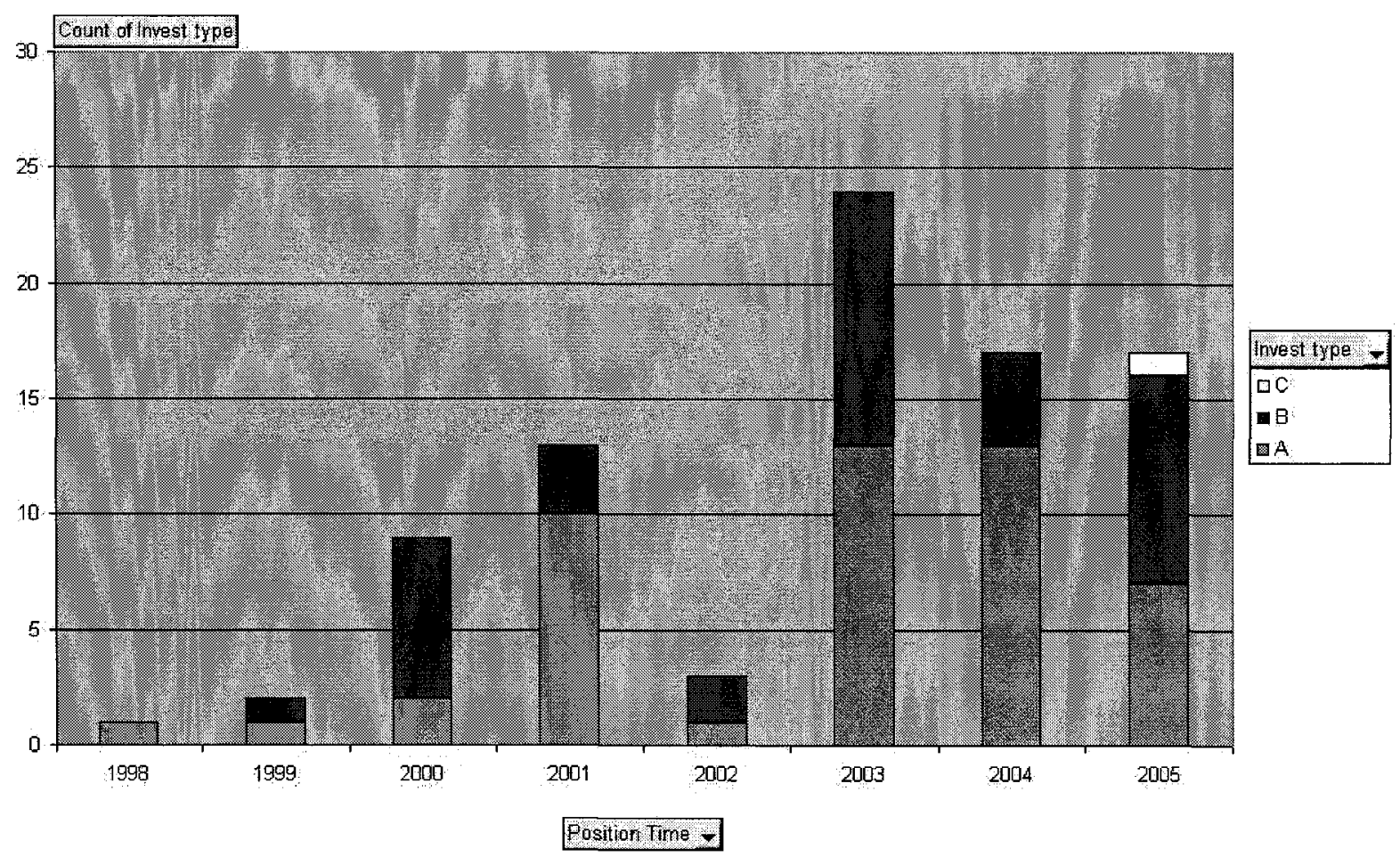




\section{Appendix 4: Investments in OSS by Symantec/VERITAS}

Symantec and VERITAS completed their merger in July 2005. Before then only VERITAS had OSS related activities. VERITAS announced Linux roadmap and open source strategy in 2000 and its products, VERITAS Volume ManagerTM, VERITAS File SystemTM, VERITAS Cluster ServerTM and VERITAS NetBackupTM server, were ported to Linux in after years. VERITAS enables Linux to become an enterprise player by its products. But according to the criteria defined in this research, there is no OSS investment found in VERITAS. OSS related activities in VERITAS may help us get better understanding on OSS investments in other companies. Figure 10 illustrates the OSS related activities in Symantec/VERITAS from 2000 to 2005. 


\section{Figure 10: Investments in OSS by Symantec/VERITAS}

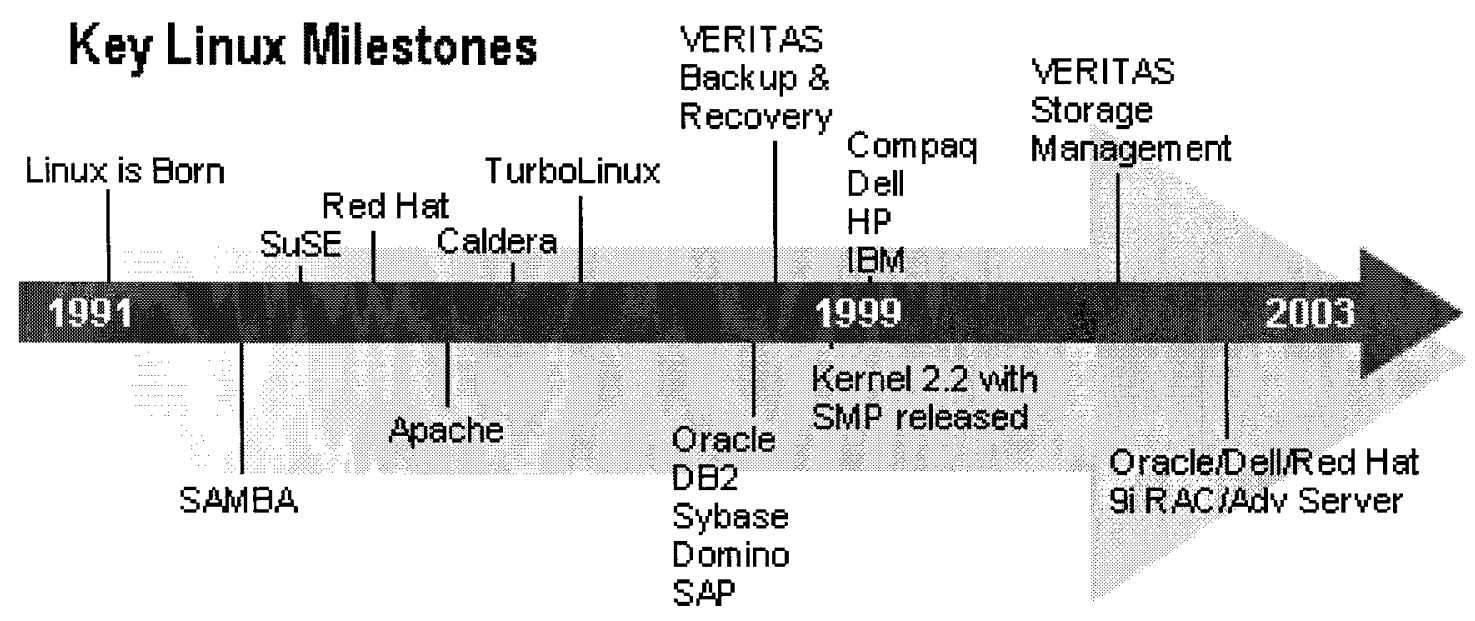

\section{Linux is Maturing in the Enterprise}

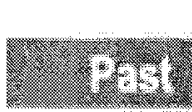

Workstations

Proxy

Firevall

Cache

Directory

E-rnail

Web, File 8 Print Servers

\section{Present}

Database Servers

Application Servers

Custom Applications

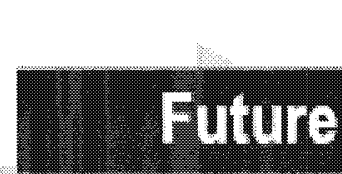

Storage Networks Mainfiame

Source: Linux roadmap and open source strategy in VERITAS, 2005

http://www.veritas.com/news/press/FeatureArticleDetail.jhtml?Newsld=9570 


\section{Appendix 5: Investments in OSS by Nokia}

Currently, Nokia hosts, contributes to, and/or sponsors multiple open source projects and initiatives. A number of developers in Nokia are directly involved in creating, refining, testing, using, and supporting open source software. Nokia also acknowledges the value in creating open source software in collaboration with others (Open Source at Nokia, 2006).

24 OSS projects are found in Nokia's official website. Among those 24 OSS projects, 10 projects were proprietary technology released to open source (OSS investment type A) and 14 projects are existing OSS projects sponsored by Nokia (OSS investment type B). Nokia made a firm commitment with Loki, which has developed open multimedia standards for gaming such as SDL, SMPEG and OpenAL, to support the open source community by developing open tools and standards in 2001. Nokia and Lutris Technologies, a leading open source enterprise software and services company, also have a licensing agreement to simplify and accelerate the creation and deployment of applications for Nokia's mobile handsets in 2001 (OSS investment type C). Nokia launched ostdev.net in 2001 and opensource.nokia.com in 2005 for OSS initiatives. In 2005, Nokia released patents for Linux kernel to support OSS development. Figure 11 illustrates the OSS investments made by Nokia from 2000 to 2005. 


\section{Figure 11: Investments in OSS by Nokia}

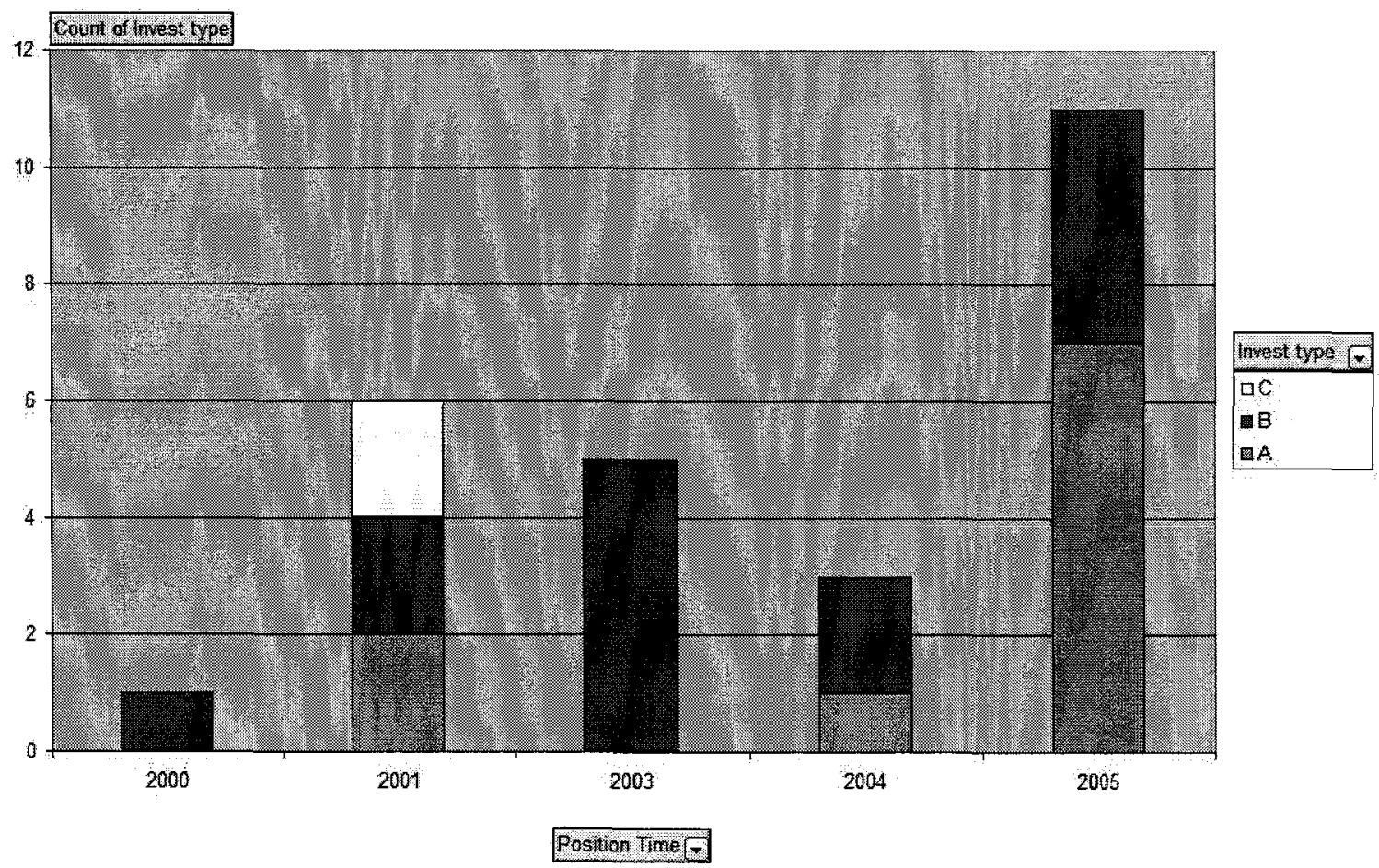




\section{Appendix 6: Investments in OSS by Other Communication Equipment Companies}

Ericsson and Red Hat became strategic partners and contributed embedded Linux in 2000 (OSS investment type B). That operating system was used in Ericsson's Cordless Screen Phone HS210.

Motorola's HA-Linux was released in 2000 and features hot-swap capability by using an integrated set of software components at the kernel and application levels (OSS investment type A). Its J2ME Open Windowing Toolkit provided in 2001 provides a core set of user interface components and permits the development of custom components (OSS investment type A). 


\section{Appendix 7: Investments in OSS by Networking and Communication Devices Companies}

Cisco Systems acquired Vovida Networks in 2000 and also acquired Vovida.org which today hosts a variety of open source software applications, protocol stacks and Voice over Internet Protocol (VoIP) related projects (OSS investment type C). Cisco released Cisco Enterprise Print System (CEPS) software for the management of large printer networks in 1999 (OSS investment type A). Cisco also launched Cisco-centric Open Source Initiative (COSI) in 2001, an Open Source Exchange community for Cisco-centric developers and customers to publish their open source scripts, tools, and utilities for use with Cisco products (OSS investment type A). In 2005, Cisco attended Open source storage development team with IBM (OSS investment type B). Figure 12 illustrates the OSS investments made by Cisco from 2000 to 2005. 


\section{Figure 12: Investments in OSS by Cisco}

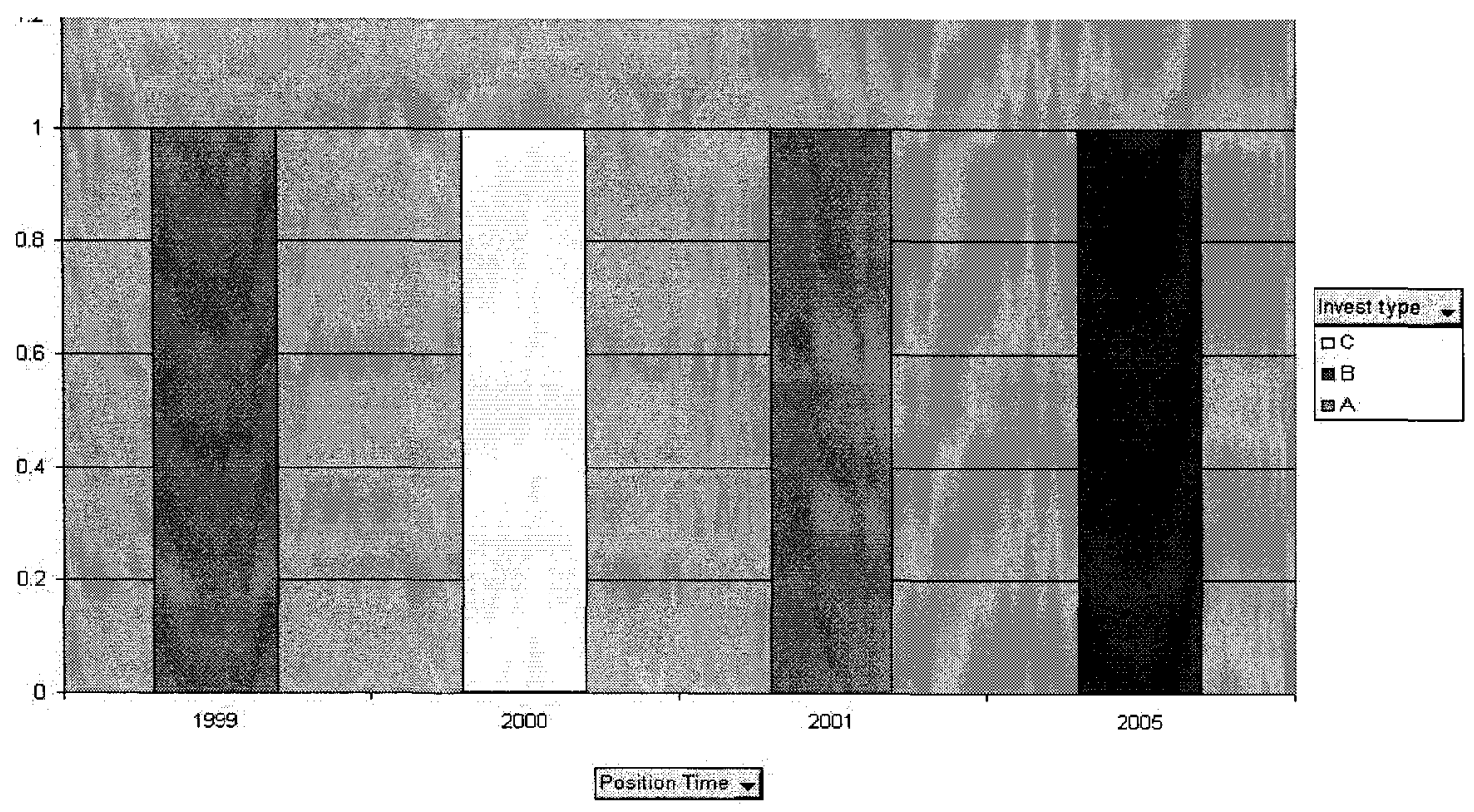

Juniper released AMT gateway and relay project in 2005 for hosts on non IP multicast capable networks to receive IP multicast in a way that is transparent to the application (OSS investment type A). 


\section{Appendix 8: Investments in OSS by Processing Systems Products Companies}

Lucent provided Not-So-Bad Distribution (NSBD), an automated distribution system that is designed for distributing open source software on the internet, in 1997, and has provided WWExptool OSS pack, a secured automatic updates of Open Source binaries, with dual license since 1999 (OSS investment type A). In 2000, Lucent released its Plan 9 computer operating system (OSS investment type A), which is the first operating system designed from the outset for production-quality distributed computing in a networked environment, under an open-source agreement. Lucent and Vita Nuova, a network operating systems software provider, announced the Inferno operating system from Lucent Technologies' Bell Labs open source. Lucent Technologies' New Ventures Group has invested in Vita Nuova to develop and market Inferno (OSS investment type C). Figure 13 illustrates the OSS investments made by Lucent from 1997 to 2005. 


\section{Figure 13: Investments in OSS by Lucent}

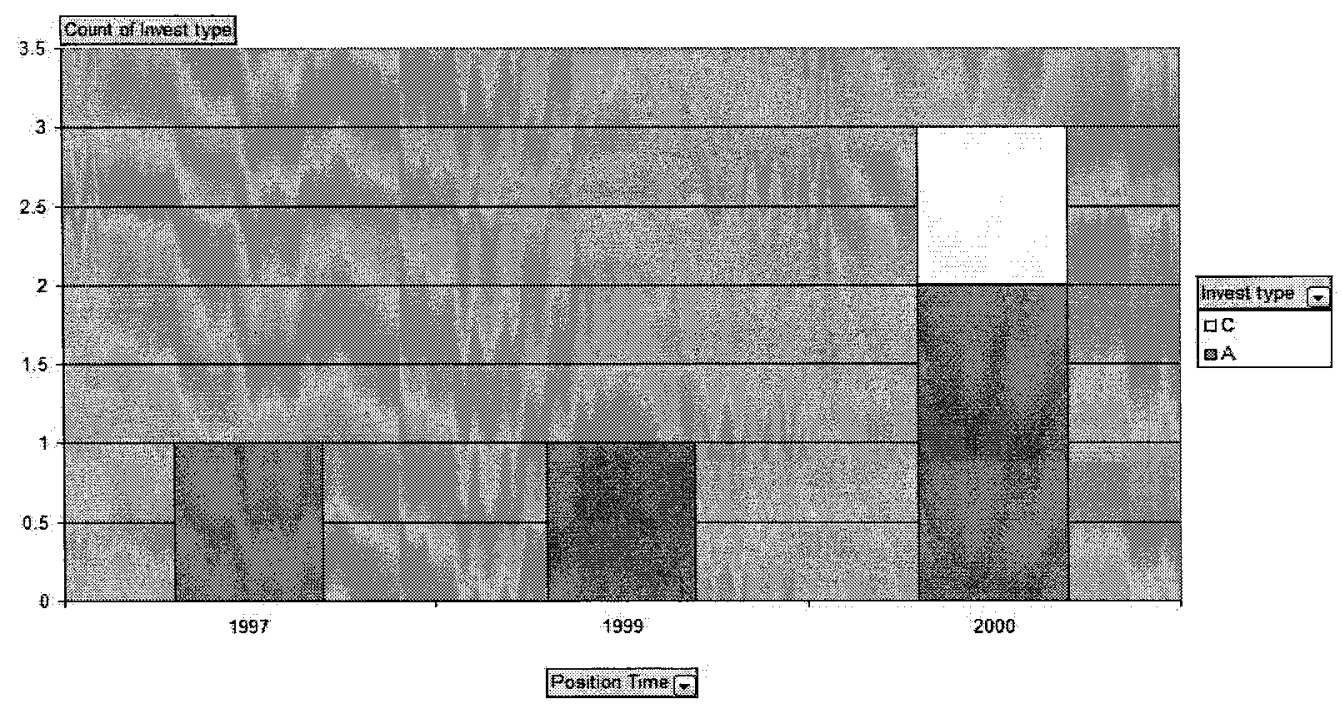

Nortel released open source AgentTrigger software for Remedy's Action Request System which uses a caller's telephone number or account number to automatically search and display the caller's history in 1999 (OSS investment type A). It provided FIPA-OS, an open source implementation of the mandatory elements contained within the FIPA specification for agent interoperability, and Open IP Environment, a unique standards-based routing software platform both in 2000 (OSS investment type A).

Avaya provides Voice Portal, a self service web based speech development, which is deployed on standard Linux/Intel/AMD servers and supports integration with market leading IP technologies. No OSS investments were found in Avaya's official website. 


\section{Appendix 9: Factors of Type A Found in Data (84 projects)}

\begin{tabular}{|c|c|c|c|c|c|c|c|c|c|c|c|c|}
\hline & Factor & Nortel & Lucent & Juniper & Cisco & Motorola & Ericsson & Nokia & Novell & Sun & HP & Total \\
\hline 1 & $\begin{array}{l}\text { OSS performs better than } \\
\text { alternatives along dimensions } \\
\text { that users care about }\end{array}$ & 2 & 4 & & 1 & 2 & & 4 & 5 & 18 & 21 & 57 \\
\hline 2 & $\begin{array}{l}\text { Use OSS for internal product } \\
\text { development }\end{array}$ & & & & & & & 6 & 4 & 5 & 17 & 32 \\
\hline 3 & Savings from using OSS & 2 & 1 & 1 & 2 & & & 3 & 6 & 10 & 5 & 30 \\
\hline 4 & Support for open standards & & & & & & & & 3 & 5 & 12 & 20 \\
\hline 5 & $\begin{array}{l}\text { Revenue from new products } \\
\text { and new markets }\end{array}$ & & 1 & & & 1 & & & 4 & 10 & & 16 \\
\hline 6 & Use as module by others & & & & & & & 2 & & 2 & 1 & 5 \\
\hline 7 & Provide users with more control & & 1 & & & 1 & & & & 3 & & 5 \\
\hline 8 & Reduce knowledge barrier & 1 & & & & & & & 1 & 1 & & 3 \\
\hline 9 & $\begin{array}{l}\text { Release code to provide } \\
\text { benefits to all adopters }\end{array}$ & 1 & 3 & & & & & & & & & 4 \\
\hline 10 & $\begin{array}{l}\text { Release code to help others } \\
\text { reduce costs }\end{array}$ & 1 & & & & 1 & & & & 1 & & 3 \\
\hline 11 & $\begin{array}{l}\text { Speed resolution of technical } \\
\text { problems }\end{array}$ & 1 & & & & 1 & & & & & & 2 \\
\hline 12 & $\begin{array}{l}\text { Establish good business } \\
\text { relationships }\end{array}$ & & & & & & & & & 1 & & 1 \\
\hline 13 & Committed to OSS strategy & & & & & & & & & 1 & & 1 \\
\hline
\end{tabular}




\section{Appendix 10: Factors of Type B Found in Data (73 projects)}

\begin{tabular}{|c|c|c|c|c|c|c|c|c|c|c|c|c|}
\hline & Factor & Nortel & Lucent & Juniper & Cisco & Motorola & Ericsson & Nokia & Novell & Sun & HP & Total \\
\hline 1 & $\begin{array}{l}\text { OSS performs better } \\
\text { than alternatives along } \\
\text { dimensions that users } \\
\text { care about }\end{array}$ & & & & & & & 9 & 8 & 10 & 15 & 42 \\
\hline 2 & $\begin{array}{l}\text { Use OSS for internal } \\
\text { product development }\end{array}$ & & & & & & 1 & 4 & 11 & 6 & 18 & 40 \\
\hline 3 & $\begin{array}{l}\text { Savings from using } \\
\text { OSS }\end{array}$ & & & & & & & 2 & 2 & 6 & 5 & 15 \\
\hline 4 & $\begin{array}{l}\text { Support for open } \\
\text { standdards }\end{array}$ & & & & & & & 1 & 2 & 3 & 11 & 17 \\
\hline 5 & $\begin{array}{l}\text { Revenue from new } \\
\text { products and new } \\
\text { markets }\end{array}$ & & & & & & & & 3 & 1 & & 4 \\
\hline 6 & $\begin{array}{l}\text { Use as module by } \\
\text { others }\end{array}$ & & & & & & & 3 & & 2 & & 5 \\
\hline 7 & $\begin{array}{l}\text { Provide users with more } \\
\text { control }\end{array}$ & & & & & & & 1 & & & & 1 \\
\hline 8 & $\begin{array}{l}\text { Reduce knowledge } \\
\text { barrier }\end{array}$ & & & & 1 & & & & & & & 1 \\
\hline 9 & $\begin{array}{l}\text { Committed to OSS } \\
\text { strategy }\end{array}$ & & & & & & & & & 1 & & 1 \\
\hline 10 & $\begin{array}{l}\text { Encourage } \\
\text { communications }\end{array}$ & & & & & & & & & 1 & & 1 \\
\hline
\end{tabular}


Appendix 11: Factors of Type C Found in Data (9 projects)

\begin{tabular}{|c|c|c|c|c|c|c|c|c|c|}
\hline & Factor & Description & Lucent & Cisco & Nokia & Novell & Sun & HP & Total \\
\hline 1 & $\begin{array}{l}\text { OSS performs better than } \\
\text { alternatives along dimensions } \\
\text { that users care about }\end{array}$ & $\begin{array}{l}\text { own related advanced } \\
\text { technology, expanding } \\
\text { capabilities }\end{array}$ & & 1 & 1 & 3 & 1 & 1 & 7 \\
\hline 2 & $\begin{array}{l}\text { Use OSS for internal product } \\
\text { development }\end{array}$ & $\begin{array}{l}\text { use technology for own } \\
\text { product }\end{array}$ & & & 2 & 3 & 1 & 1 & 7 \\
\hline 3 & Savings from using OSS & $\begin{array}{l}\text { improve technology } \\
\text { (related) }\end{array}$ & 1 & 1 & & & & & 2 \\
\hline 4 & Support for open standards & supporting open standard & & 1 & 1 & 3 & 1 & 1 & 7 \\
\hline 5 & $\begin{array}{l}\text { Revenue from new products } \\
\text { and new markets }\end{array}$ & $\begin{array}{l}\text { broader adoption of OSS } \\
\text { technology }\end{array}$ & 1 & & & 1 & 1 & & 3 \\
\hline
\end{tabular}

